\title{
Technical Study of Polychrome Arhat Figures Dated From the Song Dynasty(960-1279 CE) From the Lingyan Temple, Changqing, Shandong, China
}

\author{
Yongdong Tong \\ University of Science and Technology Beijing \\ Youzhen Cai \\ Shandong Cultural Relic Conservation and Restoration Center \\ Xuening Wang \\ Shandong Cultural Relic Conservation and Restoration Center \\ Zhimin Li \\ Shandong University

\section{Austin Nevin} \\ Courtauld Institute of Art: The Courtauld Institute of Art \\ Qinglin Ma ( $\triangle$ qinglinma226@126.com ) \\ Shandong University https://orcid.org/0000-0002-5542-2388
}

\section{Research Article}

Keywords: Lingyan Temple, Arhat statues, paint layers, scientific analysis

Posted Date: June 30th, 2021

DOI: https://doi.org/10.21203/rs.3.rs-662279/v1

License: @ (i) This work is licensed under a Creative Commons Attribution 4.0 International License. Read Full License 


\section{Abstract}

Scientific analysis revealed the materials and techniques used in the process of making the polychrome sculptures providing a solid foundation for the protection and restoration of the painted statues. In addition analysis revealed changes in colour schemes applied to the sculptures can provide the basis for the virtual restoration of the painted statues. In order carry out scientifically-informed protection and restoration of the Bodhidharma statue from the Lingyan Temple, Changqinq, Shandong, several analytical methods such as optical microscope (OM), Micro-Raman spectroscopy ( $\mu$-RS), scanning electron microscopy coupled with energy dispersive X-ray analysis (SEM-EDS) and Fourier transform infrared spectroscopy (FTIR) were employed. Analysis clearly reveal the information including the stratigraphic structure and the composition of pigment. The use of silver foils and golden yellow pyrophyllite mineral to replace gold foils were found in the gilding paint layer in the later repainting after the Song Dynasty. This work reports the coexistence of emerald green $\left(\mathrm{Cu}\left(\mathrm{C}_{2} \mathrm{H}_{3} \mathrm{O}_{2}\right)_{2} \cdot 3 \mathrm{Cu}\left(\mathrm{AsO}_{2}\right)_{2}\right)$ and the degradation product lavendulan $\left(\mathrm{NaCaCu}_{5}\left(\mathrm{AsO}_{4}\right)_{4} \mathrm{Cl} \cdot 5 \mathrm{H}_{2} \mathrm{O}\right)$ in large areas of the paint stratigraphy and on the surface confirming that the degradation of emerald green is related to the thickness of the paint layer; in thinner paint layers emerald green is transformed in lavendulan, while thicker layers of contain both lavendulan and emerald green, suggesting an environmental source of chlorides.

\section{Introduction}

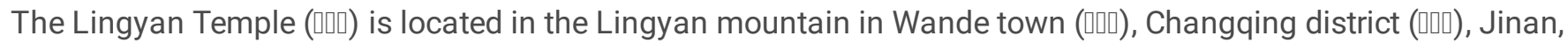
Shandong province, China, about 20 kilometers from Mount Tai (Fig.1). The temple is an important part of Mount Tai world natural and cultural heritage. As early as the Yuan-he period (806-820 CE) of the Tang Dynasty (618-907 CE), Li jifu (미), a

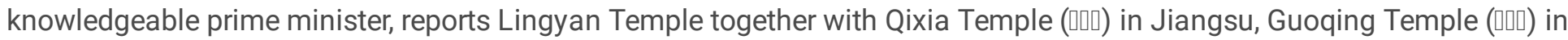
Zhejiang and Yuquan Temple (마) in Hubei as the "Four famous temples in Chinese domain". The extant stele inscriptions record that the Lingyan Temple ranked first among the four famous temples in the Song Dynasty. After the founding of the People's Republic of China, Lingyan Temple was classifies in 1982 as a national key cultural relic. There are many precious

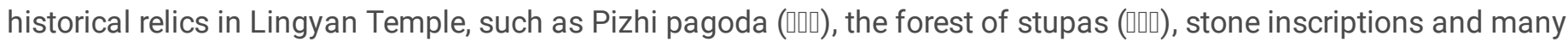
ancient buildings and ruins. Among the numerous precious historical relics, 40 painted arhat statues dating from the Song and Ming (1368-1644 CE) Dynasties are preserved in the Qianfo hall. These polychrome statues, especially the works of Song Dynasty, are skilfully sculpted with vivid and lifelike characters, and are recognized as rare masterpieces among ancient Chinese polychromy, and were once praised as the first famous statues in China by Mr. Liang Qichao (마).

In May 1981, Jinan cultural relics management committee, Jinan museum and the Changqing county LingyanTemple cultural relics management institute jointly initiated the protection and repair of the arhat statues of LingyanTemple [1]. In the process of maintenance, $\mathrm{C}-14$ dating of the wooden structures within some of the arhat sculptures determined that of the 40 arhat statues, 27 were from the Song Dynasty 13 date to the Ming Dynasty [1-2]. The objective of this paper is the technical study of the polychromy of Bodhidharma, which is a typical Song Dynasty work. This statue is colorful and rich, the expression of the characters is solemn and serene, tolerant and introspective, the work is also relatively complete, has extremely high artistic value. Bodhidharma was a native of India who came to China during the Northern and Southern Dynasties (420-589 CE) and founded Chinese zen Buddhism (ㅁ). Because of the spread and popularity of zen Buddhism in China, Bodhidharma was a household name in China. The statue of Bodhidharma was placed at the first place on the right hand side of the entrance to the hall of Qianfo (पuthe first place in the east), which meant the statue received more attention and favor from visitors than other statues.

For a long time, natural aging and many environmental factors (such as dust, smoke, roof leakage, the presence of insects, pollution.) lead to degradation of pigments, efflorescence and the flaking and peeling of paint. It is of great significance to analyze and study the paint layers of arhat statues for the subsequent conservation of cultural relics and virtual restoration. In 2018, Wang Chuanchang and others analysed samples from the sixth and seventeenth arhat statues in the east of the hall of Qianfo, and determined the mineral composition of various mineral pigments[3]. Besides that, there was

Page 2/29 
little scientific analysis and research on the paint layers of arhat statues of Lingyan Temple. Complementary and multiple analytical techniques are widely used in the study of paint layers of painted cultural relics such as polychrome statues [47], mural paintings [8-11], painted pottery [12-13] and so on, which can successfully reveal the microscopic structure of paint layers, the composition of the pigment and the priming layers, the types of binding media found in paint layers, repair materials, and the paint stratigraphy. In this paper, multiple analytical techniques including ultra depth of field 3D microscopy (OM), Micro-Raman spectroscopy ( $\mu$-RS), scanning electron microscopy coupled with energy dispersive $\mathrm{X}$-ray analysis (SEM-EDS) and Fourier transform infrared spectroscopy (FTIR) were selected to analyze the paint layers from the Bodhidharma statue. The purpose of this study is to reveal the materials and techniques used in the making the painted statues, and the changes and to the composition of the paint layers as a consequence of aging, provide basic data for the protection and restoration of the painted statue and the virtual restoration of the color texture.

\section{Materials And Methods}

\section{Materials}

A total of 19 samples were collected from different colored paint on the Bodhidharma statue. The schematic diagram of sampling position was shown in Fig. 2. Except for D1-3, D1-10, D1-19, other samples were embedded in the epoxy resin and polished.

\section{Methods}

\section{Optical microscopy (OM)}

A KEYENCE VHX-6000 ultra depth of field 3D video microscope was used to observe and document the cross sections, at magnifications from 20 to $2000 \times$. The Leica DM2700 polarizing microscope is used for the polarizing microscopic analysis of individual pigments.

\section{Scanning electron microscopy coupled with energy dispersive X-ray analysis (SEM-EDS)}

A Tescan vega3 XMU scanning electron microscope equipped with a Bruker XFlash 610M X-ray energy spectrometer was used to analyze the microstructural characteristics of paint layers and semi-quantitatively analyze the relative contents of major elements in pigment minerals in different layers. Analyses were carried out in a high vacuum environment, with a scanning voltage of $20 \mathrm{kv}, 90 \mathrm{~s}$ of acquisition time at a $15 \mathrm{~mm}$ working distance.

\section{Micro-Raman spectroscopy ( $\mu$-RS)}

A HORIBA XploRAPLUS Raman spectrometer configured with an Olympus microscope and an integrated motorized stage were used to qualitatively analyze the mineral composition of different layers under $50 \times$ and $100 \times$ objective lenses. The blue and green pigments were analysed using a $532 \mathrm{~nm}$ laser, and the other pigment were analysed using the $785 \mathrm{~nm}$ laser. The laser energy ranged from 1\%-50\%, the spectral range from $50-2000 \mathrm{~cm}^{-1}$, the collection time was $15-25 \mathrm{~s}$ with 2 acculumations. The instrument was calibrated using the $520 \mathrm{~cm}^{-1}$ silicon Raman band.

\section{Fourier transform infrared microscopy (FTIR)}

A Thermo Nicolet iN10 MX Fourier transform infrared spectroscopy was used to study the priming materials of paint layers based on the preparation of dispersions in $\mathrm{KBr}$ in the spectral range from $4000-675 \mathrm{~cm}^{-1}$, at spectral resolution of $4 \mathrm{~cm}^{-1}$.

\section{Results And Discussion}


The EDS results of relative elemental composition in each layer of the painting and the attribution from $\mu$-RS analysis are shown in Table 2. The elemental composition is given as the mass percentage after normalization treatment. In the processing of element relative content analysis, the free selection mode was used to select areas of interest within each layer. The layer sequence was numbered in the micrographs of cross sections in Fig. 3, 5 and 8 correspond to the same numbers used in EDS analysis. Organic layers that did not contain metal ions are: D1-2 L0; D1-9 L2, L5, L8, L10, L12, L14; and D1-16 L3. The elemental composition of these layers are not listed in Table 2.

\section{Analysis of stratigraphy}

The cross sections observed under the optical and scanning electron microscope clearly show that the paint layers contains multiple layers of pigments and priming layers. D1-1, D1-7and D1-9 are samples with the most layers. As shown in Fig. $3 \mathbf{a}$ and $\mathbf{b}$, D1-1 has 14 layers from the statue surface to the unpainted clay ground, among which the pigment layers have 7 layers, and the layer structure distribution are as follows: $L 1$ reddish-brown pigment layer $\rightarrow$ L2 white priming layer $\rightarrow \mathrm{L} 3$ red pigment layer $\rightarrow \mathrm{L} 4$ white priming layer $\rightarrow \mathrm{L} 5$ orange pigment layer $\rightarrow \mathrm{L} 6$ white priming layer $\rightarrow \mathrm{L} 7$ yellow pigment layer $\rightarrow$ L8 white priming layer (mixed with red pigment particles) $\rightarrow$ L9 orange pigment layer $\rightarrow$ L10 white priming layer $\rightarrow \mathrm{L} 11$ red pigment layer $\rightarrow \mathrm{L} 12$ white priming layer $\rightarrow \mathrm{L} 13$ white pigment layer $\rightarrow \mathrm{L} 14$ gray priming layer.

The structural relationship between the layers of D1-9 gilding sample can be shown more clearly from the backscatter electron image (Fig. $3 \mathbf{f}$ ). The sample from the statue surface to the unpainted clay idol totals 15 layers, including six gilding layers (L1, L4, L7, L9, L11, L13), six adhesive layers (L2, L5, L8, L10, L12, L14), two pigment layers (L3, L6), and one priming layer (L15). The layer structure of D1-7 gilding paint layer is not very clear under the optical microscope annular light source, but clearly visible under the coaxial light source and in the backscattered electron image (as shown in Fig. 3 c and d). The layer structure is basically the same as the layer structure of D1-9, but there is an extra priming layer under the 12th layer of adhesive. According to our analysis the D1-7 and D1-9 contain six gilding layers and two pigment layers demonstrating that the Bodhidharma statue has experienced at least 8 repainting treatments.

In other samples of paint there are only two layers. As seen from Fig. 5 a, sample D1-2 located on the face of the statue has only one reddish-brown pigment layer and one priming layer suggesting that the color of the face has always remained the same in the previous polychrome process. The reddish-brown pigment layer was covered with a dark translucent organic material (this translucent material is almost invisible in backscatter electron images).

The particle size distribution using the statistical analysis functions of the built-in software of the KEYENCE VHX-6000 ultradepthoffield 3D microscope were used to measure the thickness of the paint layers, the first pigment layers, the priming layers and the particles sizes of the pigment. The measurement results are shown in Table1.The thickness of the paint layers are different in different positions of the sample locations. The D1-2 paint layer on the face is only $205 \mu \mathrm{m}$, while the paint layers at the gilding are relatively thick, such as the thickness of D1-7 is $895 \mu \mathrm{m}$. The thickness of the pigment layers and the priming layers are also different, with the thinnest only $20 \mu \mathrm{m}$ and the thickest up to $570 \mu \mathrm{m}$. The thickness of gilding layers (gold foil) are only about $2 \mu \mathrm{m}$ (as determined with SEM-EDX), while the thickness of adhesive layers are about $35 \mu \mathrm{m}$. The pigment particles size of different pigment layers also varies greatly, for example, the average diameter of red pigment particles in D1-6 is approximately $5 \mu \mathrm{m}$, while the average diameter of green pigment particles in D1-15 is $40 \mu \mathrm{m}$. In Fig. 4 images of the pigment particles observed by the microscope under different light sources and the distribution maps of pigment particles were fitted by the micrograph under coaxial light source.

Table 1 Summary table of the thickness of paint layers, the thickness of the first pigment layers and the particles size of pigment 


\begin{tabular}{|c|c|c|c|}
\hline $\begin{array}{l}\text { Samples } \\
\text { No }\end{array}$ & $\begin{array}{l}\text { Thickness of } \\
\text { paint layers } / \mu \mathrm{m}\end{array}$ & $\begin{array}{l}\text { Thickness of pigment layers and priming layers } \\
/ \mu \mathrm{m}\end{array}$ & $\begin{array}{l}\text { Particles size } \\
\text { (minimum/maximum/average } \\
\text { diameter } / \mu \mathrm{m} \text { ) }\end{array}$ \\
\hline D1-1 & 580 & $\begin{array}{l}\text { L1 Reddish-brown pigment layer } 55 \text {. L2 White } \\
\text { priming layer } 85\end{array}$ & $3 / 35 / 5$ \\
\hline D1-2 & 205 & $\begin{array}{l}\text { L0 Organic layer } 30 . \text { L1 Reddish-brown pigment } \\
\text { layer } 110 \text {. L2 Gray priming layer } 60\end{array}$ & $3 / 35 / 10$ \\
\hline D1-4 & 380 & $\begin{array}{l}\text { L1 Orange pigment layer } 45 \text {. L2 White priming } \\
\text { layer } 190\end{array}$ & $3 / 40 / 20$ \\
\hline D1-5 & 560 & $\begin{array}{l}\text { L1 Blue pigment layer 20. L2 Gray priming layer } \\
95\end{array}$ & $2 / 15 / 10$ \\
\hline D1-6 & 425 & L1 Red pigment layer 30 & $2 / 30 / 5$ \\
\hline D1-7 & 895 & L1 Gold foil layer 2 & - \\
\hline D1-8 & 350 & $\begin{array}{l}\text { L1 Red pigment layer } 40 \text {. L2 White priming layer } \\
145\end{array}$ & $3 / 20 / 5$ \\
\hline D1-9 & 370 & L1 Gold foil layer 2. L2 Binding medium 35 & - \\
\hline D1-11 & 210 & L1 Black pigment layer 80 & - \\
\hline D1-12 & 225 & L1 Reddish-brown pigment layer 160 & $4 / 70 / 15$ \\
\hline D1-13 & 250 & $\begin{array}{l}\text { L1 Red pigment layer } 30 \text {. L2 Orange pigment } \\
\text { layer } 20\end{array}$ & $4 / 35 / 10$ \\
\hline D1-14 & 345 & L1 Yellow pigment layer 70 & $4 / 30 / 15$ \\
\hline D1-15 & 745 & L1 Green pigment layer 570 & $12 / 190 / 40$ \\
\hline D1-16 & 225 & $\begin{array}{l}\text { L1 Red pigment layer } 50 \text {. L2 White priming layer } \\
40\end{array}$ & $3 / 65 / 10$ \\
\hline D1-17 & 870 & L1 White pigment layer 870 & $8 / 75 / 15$ \\
\hline D1-18 & 290 & L1Blue-green pigment layer 75 & $15 / 35 / 20$ \\
\hline
\end{tabular}

The pigment layers and the priming layers usually appear alternatively, indicating that during repainting the statue was generally primed with a white layer that was applied over the last pigment layer. For the gilding layers very few priming layers are found. Instead new gold foil layers were applied directly over the last gold foil using an adhesive. In some places there is no priming layers between the old and new pigment layers. For example, the green pigment layer L1 of the D1-15 was applied directly over the red pigment layer L2 (Fig. 4 d).

Paint layers represented by D1-8 and D1-19 are clearly different from other paint layers in terms of layer structure. The whole paint layers were painted on a layer of white paper (Fig. $5 \mathbf{d}$, f, paper fibers are attached to the back of the paint layers), and the white paper was pasted over a white ground layer. Taking D1-8 as an example, the layers from the surface to the unpainted clay is as follows: Pink pigment layer $\rightarrow$ white priming layer $\rightarrow$ brown priming layer $\rightarrow$ white paper $\rightarrow$ white ground layer $\rightarrow$ clay body. D1-8 and D1-19 come from the inside of the sleeves and the black cassock area and are associated with new painting technology in the latest application of polychromy.

\section{Analysis of gilding layers}

EDS analysis show that the gold layers of D1-7 and D1-9 contains only Au and Ag except some layers (the 11 ${ }^{\text {th }}$ layer of D17 contains $3.6 \% \mathrm{Cu}$ ). The gold content of most gold layers is more than $90 \%$, which indicates that these gold layers are 
gold foils with high gold content. The thickness measured by the electron microscope are only $2 \mu \mathrm{m}$ at the thickest point. The $7^{\text {th }}$ and $9^{\text {th }}$ layers of sample D1-7 can hardly be observed under the optical microscope, while they are clearly evidenced in the backscattered electron images ( Fig. 3 d, f). EDS results showed that the two layers mainly contain $\mathrm{Cl}$ and Ag, with a mass ratio of about $1 / 3.7$ to 1/3.2. The Raman spectrum of white particles in layer 7 (Fig. 6 a) showed characteristic bands at $147 \mathrm{vs}, 221 \mathrm{~m}, 292 \mathrm{~m} \mathrm{~cm}^{-1}$ similar to chlorargyrite (AgCl, Fig. 6 b). Combined with the results of EDS, it can be inferred that the main phase of $\mathrm{D} 1-7 \mathrm{~L} 7$ and $\mathrm{L} 9$ are chlorargyrite $(\mathrm{AgCl})$. In terms of thickness and stratigraphic structure, D1-7 L7, L9 are only 1-2 $\mu \mathrm{m}$ in thickness like other gold foil layers. Therefore, these two layers were silver foil that was pasted on the statue surface at two separate times. Corrosion later transformed the silver foils into chlorargyrite $(\mathrm{AgCl})$.

The L3 and L6 of D1-7 and D1-9 paint layers appear golden yellow in cross-section with mineral granularity (Fig. $3 \mathbf{c}, \mathbf{e})$. The four layers of golden yellow material were painted over gold foil layers. From the color and its layer position, it can be confirmed that these layers were applied over gold foils. The results of EDS show that these four layers mainly contain Al, $\mathrm{Si}, \mathrm{K}, \mathrm{Ca}$, Fe. In addition, D1-9 L3 contains 8\% Au, which is due to the curious inclusion of gold particles in this layer (Fig. 3 e). The Raman spectrum of golden yellow particles in layer 3 (Fig. 6 c) showed characteristic bands at $216 \mathrm{~m}, 260 \mathrm{vs}, 705 \mathrm{~m}$ $\mathrm{cm}^{-1}$ similar to pyrophyllite $\left(\mathrm{Al}_{2} \mathrm{Si}_{4} \mathrm{O}_{10}(\mathrm{OH})_{2}\right.$, Fig. $\left.6 \mathrm{~d}\right)$. Combined with the results of EDS, it can be inferred that the main phase of the L3 and L6 of D1-7 and D1-9 are high iron pyrophyllite mineral.

In ancient China, especially since the Song Dynasty (960-1279 CE), the decorative technology of embossed painting and gilding ( use of silver foil and gold mixed with golden yellow mineral to replace gold foil used in the decorating Buddha statues is rarely mentioned in the literature. The discovery of silver foil layers and golden yellow pyrophyllite mineral with gold in D1-7 suggests that there were other alternatives to gold that were employed to imitate gilding.

\section{Analysis of the priming layers}

In terms of element distribution, the priming under the pigment layers can be roughly divided into five types. The first type is the white mineral dominated by $\mathrm{Al}, \mathrm{Si}(\mathrm{Al} / \mathrm{Si}$ ratio between 1/2-1/1.2) and containing a small amount of $\mathrm{K}, \mathrm{Fe}, \mathrm{Ca}, \mathrm{Pb}$ and other elements, such as D1-1 with priming layers, D1-2 L2, D1-5 L2 L4 L6, D1-6 L2 L4 L6 L8, D1-11 L5. These white mixtures showed no obvious Raman scattering except quartz particles. In order to determine the mineral phase of the priming layers mineral, three samples with simple layer structure, D1-2, D1-5, D1-6, were selected for FTIR analysis. Fig. 7 A, $B$ and $C$ are the infrared spectra of the above three samples respectively, and their main infrared characteristic absorption bands are basically one-to-one corresponding to the infrared characteristic absorption bands of kaolin [14]. Among them, the bands at $3696,3651 \mathrm{~cm}^{-1}$ corresponds to the stretching vibration of $\mathrm{Al} \otimes \mathrm{OH}$ bond outside the kaolinite octahedron structure, the band at $3620 \mathrm{~cm}^{-1}$ corresponds to the stretching vibration of Al区OH bond within the kaolinite structure. The absorption band at $1630 \mathrm{~cm}^{-1}$ is the vibration band of attached water, 1113,1033 and the band at $1007 \mathrm{~cm}^{-1}$ corresponds to the stretching vibration of Si $\mathrm{O}$ bond, $937 \mathrm{~cm}^{-1}$ corresponds to the vibration of Si区O凶Al bond, $912 \mathrm{~cm}^{-1}$ corresponds to the bending vibration of AlखO bands of Si凶O, Si凶Si and Si凶Al generated by associated quartz and feldspar. The band near 538, 470, $432 \mathrm{~cm}^{-1}$ corresponds to the bending vibration of Si $\mathrm{O}$. In addition to the characteristic bands of kaolin, there are obvious infrared characteristic bands at 2924, 2851, 1710, 1406, 1385 and $1100 \mathrm{~cm}^{-1}$ in the infrared spectrum of D1-2 sample. These characteristic bands could be related to the organic layer of the sample LO.

The second type of priming layer mineral dominated by Al and Si elements(Al/Si ratio between 1/2-1/1.2) and containing $\mathrm{Pb}$, including D1-4L2, D1-11L2, D1-13L4, L5 and L6, which contain 30\%-45\% Pb. Lead white $\left(2 \mathrm{PbCO}_{3} \cdot \mathrm{Pb}(\mathrm{OH})_{2}\right)$ particles were identified with Raman spectroscopy in layers D1-4 L2 and D1-13 L4. Therefore, it can be inferred that these leaded priming layers are mixtures of kaolin and different proportion of lead white. The third type of priming layer mineral 
dominated by $\mathrm{Ca}$ and $\mathrm{Pb}$. For example, the contents of $\mathrm{Ca}$ and $\mathrm{Pb}$ in $\mathrm{D} 1-4 \mathrm{~L} 4$ are $57 \%$ and $38 \%$, while the contents of $\mathrm{Al}$ and Si are only $2 \%$ and $3 \%$. Micro Raman spectroscopy revealed two white minerals, chalk $\left(\mathrm{CaCO}_{3}\right)$ and lead white. D1-4 L4 is composed of chalk and lead white, mixed with a small amount of kaolin. The fourth type of priming layer mineral dominated by Pb, such as D1-11 L4 and D1-15 L4, containing chiefly lead white with Pb content in the two layers as high as $85 \%$ and $60 \%$ respectively. $\mu$-RS confirmed that the main mineral phase in these two layers is lead white, so this type of priming is lead white with a small amount of kaolin added. The fifth type of priming layer mineral dominated by $\mathrm{Si}, \mathrm{Al}, \mathrm{Ca}$, and containing a certain amount Fe. For example, under the pink pigment layer of D1-8 sample, there are two priming layers of white and brown, and the $\mathrm{Al} / \mathrm{Si}$ ratio of their chemical composition are 1:3 respectively. Both of these two layers contain $\mathrm{Fe}$ (the white layer $13 \%$ and the brown layer 16\%), which is different from other kaolin-based priming layers mineral in chemical composition. The priming of these two layers have no obvious Raman activity. According to the relative content of elements, it can be inferred that the white priming layer should be a low aluminum and high calcium clay, while the brown priming layer is a low aluminum and high iron clay.

In summary, the priming layers material used in the each previous polychrome of the statue is mostly white kaolin or a mixture of other white minerals based on kaolin as the matrix. The use of low aluminum and high iron priming in D1-8 is obviously different from other paint layers.

Table 2. Results of SEM-EDS and $\mu$-RS analysis

\section{Analysis of pigment layers}

The results of $\mu$-RS analysis of mineral pigments in each pigment layers were shown in Table 2. Raman analysis were based on published literature [15-16]. Raman spectra of some pigments are shown in Fig. 9 and 10.

\section{Reddish-brown pigment layers}

The reddish-brown pigment layers have three layers: D1-1 L1, D1-2 L1 and D1-12 L1. $\mu-R S$ analysis show that the D1-1 L1 and D1-2 L1 pigment layers are composed of hematite $\left(\mathrm{Fe}_{2} \mathrm{O}_{3}\right)$ and red lead $\left(\mathrm{Pb}_{3} \mathrm{O}_{4}\right)$. EDS analysis show that the Fe content in the two layers are significantly different $(17 \%, 31 \%$, respectively), indicates that the mineral ratio of pigments was different due to the different color requirements of the pigment layers at different locations (D1-2 L1 is darker in color than D1-1 L1). The pedestal area represented by D1-12 L1 is reddish-brown (Fig. 1), while the pigment layer presents a bright orange-red on the cross section (Fig. 4 a). Raman analysis shows that the orange-red mineral is red lead $\left(\mathrm{Pb}_{3} \mathrm{O}_{4}\right)$. The change from bright orange-red color to reddish-brown color on the exposed surface of the pigment layer should be related to the oxidation and deterioration of red lead pigments, and it is well known that red lead can alter to brown-black lead dioxide $\left(\mathrm{PbO}_{2}\right)$ in high humidity environment[17-19].

\section{Red pigment layers}

There are 8 layers of red pigment layers: D1-1 L3, L11, D1-5 L5, D1-6 L1, D1-13 L1, L3, D1-15 L3, L5. Raman analysis show that the mineral composition of red pigment layers are all single mineral of cinnabar (HgS) except for D1-5 L5. EDS analysis results also showed that these pigment layers mainly contain $\mathrm{Hg}$ and $\mathrm{S}$ except for a small amount of $\mathrm{Si}, \mathrm{Al}, \mathrm{Ca}$ and other elements. D1-5 L5 was made of two minerals, cinnabar and red lead.

\section{Orange pigment layers}

There are 7 layers of orange pigment layers: D1-1 L5, L9, D1-4 L1, D1-11 L3, D1-13 L2, D1-14 L3 and D1-16 L4. $\mu-R S$ analysis show that the mineral phase of D1-16 L4 is hematite $\left(\mathrm{Fe}_{2} \mathrm{O}_{3}\right)$, and the rest of the pigment layers are all red lead $\left(\mathrm{Pb}_{3} \mathrm{O}_{4}\right)$. EDS analysis results show that the content of $\mathrm{Pb}$ in the pigment layers containing red lead are above $90 \%$, which 


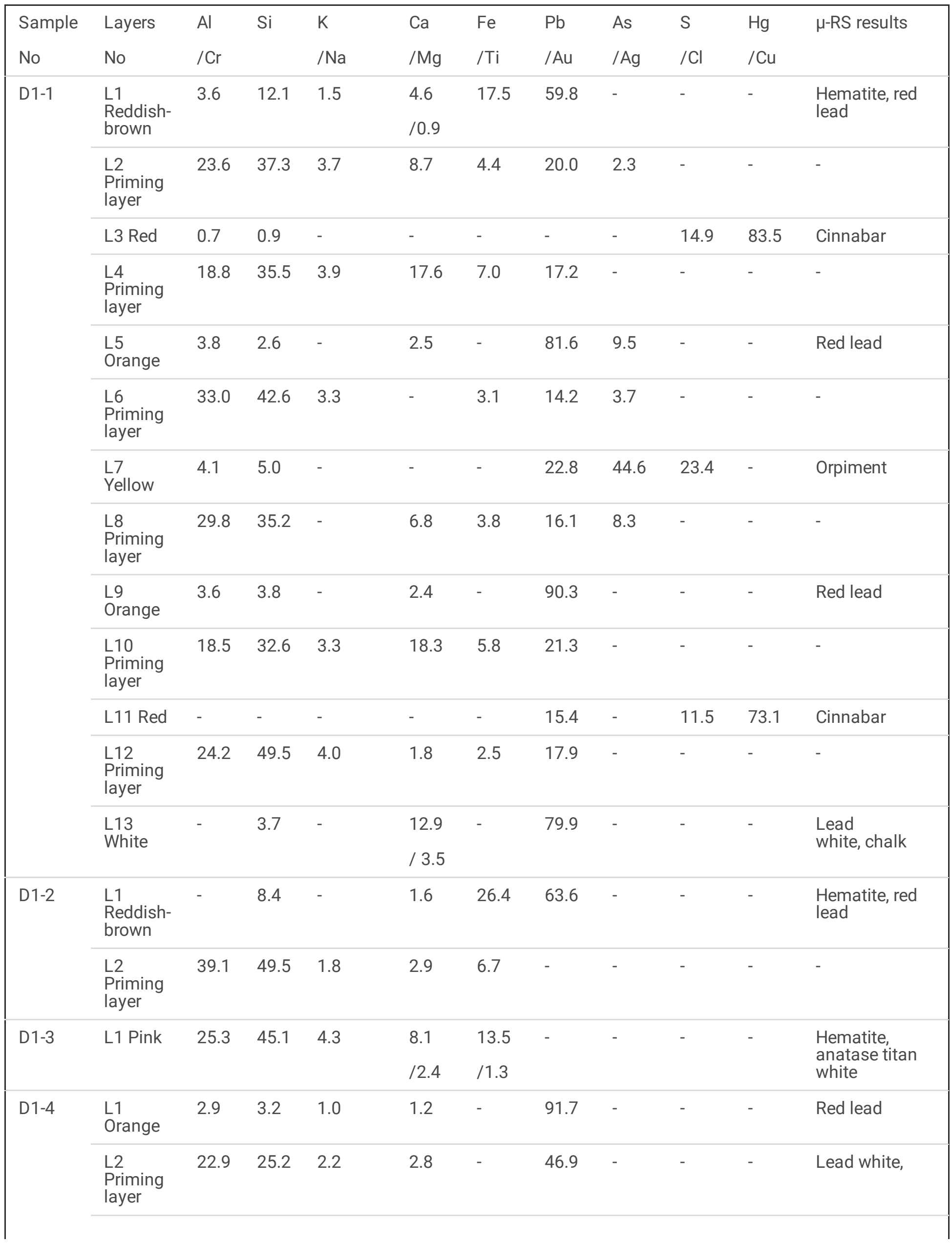




\begin{tabular}{|c|c|c|c|c|c|c|c|c|c|c|c|}
\hline & $\begin{array}{l}\text { L3 } \\
\text { White }\end{array}$ & 1.4 & 1.8 & - & 11.9 & - & 84.9 & - & - & - & $\begin{array}{l}\text { Lead } \\
\text { white, chalk }\end{array}$ \\
\hline & $\begin{array}{l}\text { L4 } \\
\text { Priming } \\
\text { layer }\end{array}$ & 1.5 & 3.3 & - & 56.5 & - & 38.7 & - & - & - & $\begin{array}{l}\text { Chalk, lead } \\
\text { white, }\end{array}$ \\
\hline \multirow[t]{9}{*}{ D1-5 } & L1 Blue & 13.8 & 23.6 & $/ 1.5$ & 43.8 & 4.0 & 10.5 & & & $/ 2.7$ & Azurite, chalk \\
\hline & $\begin{array}{l}\text { L2 } \\
\text { Priming } \\
\text { layer }\end{array}$ & 37.3 & 52.5 & 5.4 & - & 4.8 & - & - & - & - & - \\
\hline & $\begin{array}{l}\text { L3 } \\
\text { White }\end{array}$ & 0.6 & 0.7 & - & - & - & 98.7 & - & - & - & Lead white \\
\hline & $\begin{array}{l}\text { L4 } \\
\text { Priming } \\
\text { layer }\end{array}$ & 27.1 & 53.3 & 7.4 & 3.0 & 2.7 & 6.5 & - & - & - & - \\
\hline & L5 Red & 6.5 & 6.8 & 3.5 & $\begin{array}{l}9.8 \\
/ 3.9\end{array}$ & - & 33.8 & - & 9.1 & 26.7 & $\begin{array}{l}\text { Cinnabar, red } \\
\text { lead }\end{array}$ \\
\hline & $\begin{array}{l}\text { L6 } \\
\text { Priming } \\
\text { layer }\end{array}$ & 31.1 & 51.6 & 8.6 & 4.5 & 4.2 & - & - & - & - & \\
\hline & $\begin{array}{l}\text { L7 } \\
\text { Green }\end{array}$ & 4.1 & 22.4 & - & 29.1 & - & - & - & - & $/ 32.4$ & \\
\hline & & & & & $/ 12.1$ & & & & & & \\
\hline & $\begin{array}{l}\text { L8 } \\
\text { Priming } \\
\text { layer }\end{array}$ & 18.5 & 23.6 & 2.8 & 52.0 & 3.1 & - & - & - & & \\
\hline \multirow[t]{9}{*}{ D1-6 } & L1 Red & - & - & - & 1.7 & - & - & - & 21.3 & 77.0 & Cinnabar \\
\hline & $\begin{array}{l}\text { L2 } \\
\text { Priming } \\
\text { layer }\end{array}$ & 30.7 & 50.3 & 8.4 & 10.6 & - & - & - & - & - & \\
\hline & $\begin{array}{l}\text { L3 } \\
\text { White }\end{array}$ & - & 4.6 & - & 29.2 & - & 52.6 & - & - & - & $\begin{array}{l}\text { Chalk, } \\
\text { magnesite, }\end{array}$ \\
\hline & & & & & 113.6 & & & & & & lead white \\
\hline & $\begin{array}{l}\text { L4 } \\
\text { Priming } \\
\text { layer }\end{array}$ & 38.0 & 51.9 & 6.6 & 3.6 & - & - & - & - & - & \\
\hline & $\begin{array}{l}\text { L5 } \\
\text { White }\end{array}$ & 0.8 & - & - & 1.3 & - & 97.9 & - & - & - & Lead white \\
\hline & $\begin{array}{l}\text { L6 } \\
\text { Priming } \\
\text { layer }\end{array}$ & 27.7 & 59.2 & 8.3 & 1.8 & 3.0 & - & - & - & - & \\
\hline & $\begin{array}{l}\text { L7 } \\
\text { White }\end{array}$ & 1.4 & 0.9 & - & 1.0 & - & 96.7 & - & - & - & Lead white \\
\hline & $\begin{array}{l}\text { L8 } \\
\text { Priming } \\
\text { layer }\end{array}$ & 37.9 & 50.5 & 5.9 & - & 5.7 & - & - & - & - & \\
\hline \multirow[t]{2}{*}{ D1-7 } & L1 Gold & - & - & - & - & - & /89.1 & $/ 10.9$ & & - & \\
\hline & $\begin{array}{l}\text { L3 } \\
\text { Golden }\end{array}$ & 23.6 & 43.1 & 5.7 & 4.0 & 23.6 & - & - & - & - & Pyrophyllite \\
\hline
\end{tabular}




\begin{tabular}{|c|c|c|c|c|c|c|c|c|c|c|c|}
\hline \multicolumn{12}{|c|}{ yellow } \\
\hline & L4 Gold & - & - & - & - & - & /93.1 & \multicolumn{2}{|l|}{ /6.9 } & \multicolumn{2}{|l|}{-} \\
\hline & $\begin{array}{l}\text { L6 } \\
\text { Golden } \\
\text { yellow }\end{array}$ & 27.1 & 37.1 & 5.5 & 3.2 & 25.3 & & & & \multicolumn{2}{|l|}{$/ 1.8$} \\
\hline & L7 Silver & - & - & - & - & - & - & /78.6 & $/ 21.4$ & & \\
\hline & L9 Silver & - & - & - & - & - & - & /73.6 & /23.0 & $/ 3.4$ & \\
\hline & $\begin{array}{l}\text { L11 } \\
\text { Gold }\end{array}$ & - & - & - & - & - & /89.1 & $/ 7.3$ & & /3.6 & \\
\hline \multirow[t]{4}{*}{ D1-8 } & L1 Pink & 8.5 & 24.0 & - & 37.1 & 19.0 & - & - & 3.0 & - & Hematite, chalk \\
\hline & & & & & /8.4 & & & & & & \\
\hline & $\begin{array}{l}\text { L2 } \\
\text { Priming } \\
\text { layer }\end{array}$ & 12.8 & 42.0 & 5.5 & 26.7 & 13.0 & - & - & - & - & \\
\hline & $\begin{array}{l}\text { L3 } \\
\text { Priming } \\
\text { layer }\end{array}$ & 16.5 & 49.1 & 7.9 & 10.3 & 16.2 & - & - & - & - & \\
\hline \multirow[t]{6}{*}{ D1-9 } & L1 Gold & - & - & - & - & - & /97.4 & \multicolumn{2}{|l|}{ /2.6 } & - & \\
\hline & $\begin{array}{l}\text { L3 } \\
\text { Golden } \\
\text { yellow }\end{array}$ & 18.9 & 45.6 & 4.2 & 3.6 & 19.5 & $/ 8.2$ & \multicolumn{2}{|l|}{-} & - & \\
\hline & L4 Gold & - & - & - & - & - & /96.7 & \multicolumn{2}{|l|}{ /3.3 } & - & \\
\hline & $\begin{array}{l}\text { L6 } \\
\text { Golden } \\
\text { yellow }\end{array}$ & 28.8 & 38.2 & 5.8 & 5.2 & 22.0 & - & - & - & - & \\
\hline & L7 Gold & - & - & - & - & - & /96.6 & \multicolumn{2}{|l|}{5.4} & - & \\
\hline & $\begin{array}{l}\text { L13 } \\
\text { Gold }\end{array}$ & - & - & - & - & - & /90.2 & \multicolumn{2}{|l|}{9.8} & - & \\
\hline \multirow[t]{2}{*}{ D1-10 } & L1 Blue & 19.9 & 34.1 & $2.8 / 19.4$ & 1.1 & - & - & \multirow[t]{2}{*}{-} & 21.1 & - & \multirow[t]{2}{*}{ Ultramarine } \\
\hline & & & & & & & & & $/ 1.6$ & & \\
\hline \multirow[t]{5}{*}{ D1-11 } & L1 Black & & & & & & & & & & \multirow[t]{2}{*}{ Lamp black } \\
\hline & $\begin{array}{l}\text { L2 } \\
\text { Priming } \\
\text { layer }\end{array}$ & 27.7 & 32.8 & - & 9.2 & $/ 0.5$ & 29.8 & - & - & - & \\
\hline & $\begin{array}{l}\text { L3 } \\
\text { Orange }\end{array}$ & 1.9 & 1.5 & - & 1.4 & - & 88.4 & - & /6.8 & - & Red lead \\
\hline & $\begin{array}{l}\text { L4 } \\
\text { Priming } \\
\text { layer }\end{array}$ & 3.3 & 3.6 & - & - & - & 83.4 & - & /9.7 & - & Lead white \\
\hline & $\begin{array}{l}\text { L5 } \\
\text { Priming } \\
\text { layer }\end{array}$ & 28.1 & 48.3 & 3.9 & - & /0.7 & 19.1 & - & - & - & \\
\hline D1-12 & $\begin{array}{l}\text { L1 } \\
\text { Reddish- } \\
\text { brown }\end{array}$ & 0.5 & - & - & 0.4 & - & 95.4 & - & /3.7 & - & Red lead \\
\hline
\end{tabular}




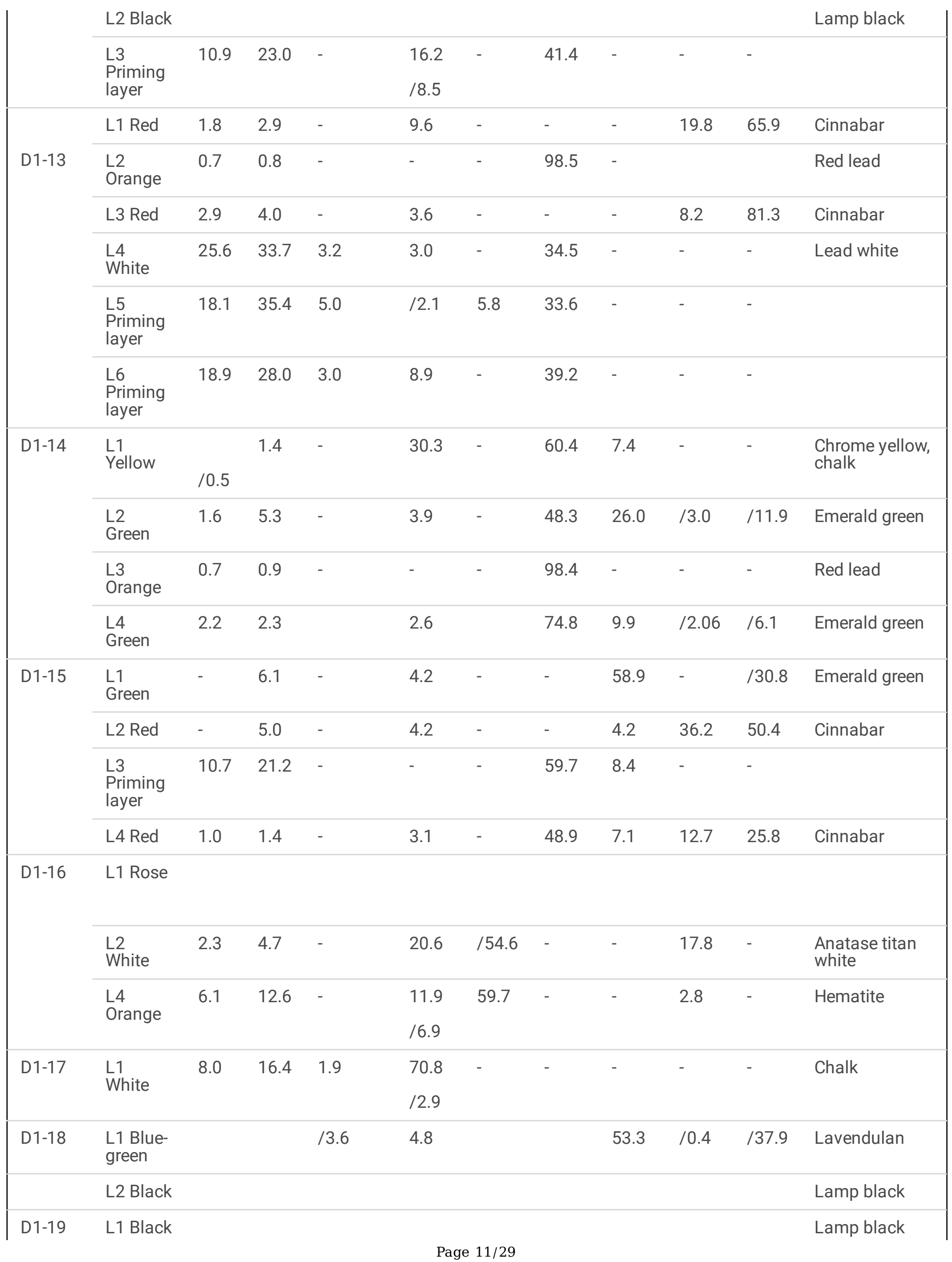


indicates that these pigment layers are basically composed of pure red lead.

\section{Pink pigment layers}

The pink pigment layers are D1-3 L1 and D1-8 L1. D1-3 L1 was composed of hematite $\left(\mathrm{Fe}_{2} \mathrm{O}_{3}\right)$ and anatase titan white $\left(\mathrm{TiO}_{2}\right)$, while D1-8 $\mathrm{L} 1$ was composed of hematite and chalk $\left(\mathrm{CaCO}_{3}\right)$ (the relative mass ratio of $\mathrm{Ca}(\mathrm{Mg})$ to Fe element is 2.4/1). The pink paint layer D1-3 L1 is directly painted on the unpainted clay idol (See additional Fig. 1). This is obviously different from the characteristics of paint layer painted over white paper in D1-8 L1, so it can be inferred that the pink area of hematite + anatase titan white in D1-3 L1 is the repair area after partial damage and shedding of the original hematite + chalk pink area.

\section{Blue pigment layers}

The blue pigment layers are D1-5 L1 and D1-10 L1. Raman analysis shows that the blue mineral in D1-5 L1 is azurite $\left(\mathrm{Cu}_{3}\left(\mathrm{CO}_{3}\right)_{2}(\mathrm{OH})_{2}\right)$, and there are white chalk $\left(\mathrm{CaCO}_{3}\right)$ particles mixed in L1. D1-10 L1 blue pigment's Raman characteristic bands at $258 \mathrm{w}, 548 \mathrm{vs}, 1091 \mathrm{~m} \mathrm{~cm}^{-1}$ (Fig. 9 j) are completely consistent with the bands of ultramarine. Raman spectroscopy and chemical composition can not distinguish natural and synthetic ultramarine pigment, but polarizing microscope analysis is an effective and simple method. Natural ultramarine pigment is made of lapis lazuli mineral grinding, because lapis lazuli mineral is often accompanied by diopside, calcite, pyrite, so there are more impurities in the pigment; particle shape is irregular, angular, particle diameter in 10 20 $\mu \mathrm{m}$. But artificial ultramarine pigment is pure in texture, and the particle shape is regular, uniform and fine (average diameter is $5 \mu \mathrm{m}$ ) [20]. D1-10 L1 blue pigment is bright and colorful under plane polarized light (Fig. 8 a), with pure texture, smooth particle edge, particle diameter of 3-6 $\mu$ m, completely extinction under orthogonal polarized light (Fig. 8 b), which corresponds to the characteristics of artificial ultramarine pigment $\left(\mathrm{Na}_{6-10} \mathrm{Al}_{6} \mathrm{Si}_{6} \mathrm{O}_{24} \mathrm{~S}_{2-4}\right)$.

\section{Yellow pigment layers}

There are 6 layers of yellow pigment layers: D1-1 L7, D1-14 L1, D1-7 L3, L6, D1-9 L3, L6. As discussed in the "Analysis of gilding layers" section, the gold in D1-7 and D1-9 L3, L6 is a clay with a high iron content that was used to replace gold foil. D1-1 L7 mainly contains As, S, Pb, and Raman analysis shows that the main mineral phase is orpiment $\left(\mathrm{As}_{2} \mathrm{~S}_{3}\right)$. In cross sections of D1-14 L1(Fig. $10 \mathrm{~d}$ ), it can be clearly seen that yellow mineral particles and white mineral particles are mixed together. According to Raman analysis, yellow pigment particles are lead chrome yellow $\left(\mathrm{PbCrO}_{4}, \mathrm{Fig} .10\right.$ e), and white pigment particles are chalk $\left(\mathrm{CaCO}_{3}\right)$.

\section{White pigment layers}

There are 7 layers of white pigment layers: D1-1 L13, D1-4 L3, D1-5 L3, D1-6 L3, L5, L7, D1-17 L1. The Ca element in D1-17 $\mathrm{L} 1$ is as high as $70.8 \%$, and Raman analysis shows that the main mineral is chalk $\left(\mathrm{CaCO}_{3}\right)$. D1-6 L3 mainly contains Pb, Ca and $\mathrm{Mg}$. Raman analysis shows that the main mineral phase in layers are lead white $\left(2 \mathrm{PbCO}_{3} \cdot \mathrm{Pb}(\mathrm{OH})_{2}\right)$, chalk, and magnesite $\left(\mathrm{MgCO}_{3}\right)$. Both D1-1 L13 and D1-4 L3 mainly contain Pb, Ca, and the relative contents of the two elements are about $80 \%$ and $12 \%$. Combined with Raman analysis, these two layers are lead white and chalk. The relative content of $\mathrm{Pb}$ in the other white pigment layers (D1-5 L3, D1-6 L5, L7) are as high as 96\%, and Raman analysis shows that the main mineral phase is lead white.

\section{Green pigment layers}

There are 5 layers of green pigment layers: D1-5 L7, D1-14 L2, D1-14 L4, D1-15 L1, D1-18 L1. D1-5 L7 mainly contains Cu, $\mathrm{Ca}, \mathrm{Mg}$ and $\mathrm{Si}$, among which $\mathrm{Cu}$ content is the highest (32\%). The green pigment layer showed no obvious Raman activity. Because the pigment layer appears glassy under microscope (Fig. 9 c), it is likely that the layer is a copper-containing 
pigment in a glassy state. D1-14 L2, L4 and D1-15 L1 mainly contain Cu and As, with characteristic Raman bands at 122w, 154vs, 175vs, 217vs, 242vs, 294m, 325m, 371m, 429m, 492m, 539m, 637vs, 685w, 760w, 835w, 951m cm (Fig. $10 \mathrm{f}$ ) corresponding to bands emerald green pigment $\left(\mathrm{Cu}\left(\mathrm{C}_{2} \mathrm{H}_{3} \mathrm{O}_{2}\right) 2 \cdot 3 \mathrm{Cu}\left(\mathrm{AsO}_{2}\right)_{2}\right)$. D1-18 $\mathrm{L} 1$ minerals are blue-green in color and contain As, $\mathrm{Cu}, \mathrm{Ca}, \mathrm{Na}$ and $\mathrm{Cl}$. The Raman spectrum(Fig. $10 \mathrm{~h}$ ) shows bands at $178 \mathrm{w}, 544 \mathrm{~m}$ and $856 \mathrm{vs} \mathrm{\textrm {cm } ^ { - 1 } \rrbracket a n d ~ i s ~}$ identified as Lavendulan (RRUFF ID: R141212).

Lavendulan $\left(\mathrm{NaCaCu}_{5}\left(\mathrm{AsO}_{4}\right)_{4} \mathrm{Cl} \cdot 5 \mathrm{H}_{2} \mathrm{O}\right)$ is a rare supergene arsenate mineral in oxidation zones of $\mathrm{Cu}$ - and As-bearing ore bodies [21]. It was first described by Breithaupt in 1837 and named as a mineral containing As, Co, Ni; Vogl (1853) describes it as blue coating from Jáchymov; Foshag (1924a) published a detailed description of lavendulan and gave its refractive index [22]. Guillemin (1956a) first used X-ray diffraction analysis to study lavendulan and proposed its original rhombic crystal structure. The mineral, which has a vivid blue-green color and a small spherical or wafer-like microstructure, is often found in arid climates, and in caves derived from copper sulfides in cave walls. Also, it has been reported as an alteration products in ancient slag heaps. Further, it is certain that some of these minerals are of archaeological significance and it is apparent that they were used for cosmetics in ancient Egypt [23].

Lavendulan has also been found sporadically in Chinese polychromy such as the painted clay statue in Yungang Grottoes

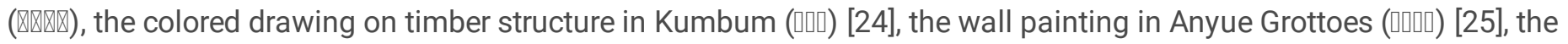
painted statues on Baoding Mountain in Dazu (समाय) [26-28], and the paintings of the Maidservant in the Saint Mother's Hall of Jinci Temple (ㅁ) [28]. The distribution of lavendulan is extremely rare in nature. Due to its physical microscopic structure and the fact that the chemical composition is similar to the widely-used emerald green pigment from the 1830 s to the early 20th century. Chinese scholars believe that the lavendulan found in polychromy is most likely an alteration product from emerald green pigment, and was not intentionally used as the blue-green pigment [24-28].

In literature [28], the mechanism of corrosion conversion of emerald green pigment into lavendulan has been studied in depth. It is suggested that emerald green $\left(\mathrm{Cu}\left(\mathrm{C}_{2} \mathrm{H}_{3} \mathrm{O}_{2}\right)_{2} \cdot 3 \mathrm{Cu}\left(\mathrm{AsO}_{2}\right)_{2}\right)$ was firstly dissociated copper ions $\left(\mathrm{Cu}^{2+}\right)$ and arsenite ions $\left(\left(\mathrm{AsO}_{2}\right)^{\square}\right)$ in a slightly acidic and humidity environment. The $\left(\mathrm{AsO}_{2}\right)^{\square}$ was oxidized to arsenate ion $\left(\left(\mathrm{AsO}_{4}\right)^{3 \rrbracket}\right)$, and finally $\mathrm{Cu}^{2+},\left(\mathrm{AsO}_{4}\right)^{3 \rrbracket}$ reacts with soluble $\mathrm{K}^{+}, \mathrm{Ca}^{2+}, \mathrm{Cl}^{\square}$ from the environment to produce lavendulan. There are no residual emerald green pigment particles were found in the blue-green pigment layer D1-18 L1. However, the simultaneous presence of layers of green and blue-green pigments can be seen in other blue-green pigment areas (Fig. 10 a), which shows the signs of green emerald green transformation into blue-green lavendulan. Therefore, it can be inferred that the blue-green pigment layer D1-18 L1 (the part of plant and flower pattern above the black pigment layer of the cassock of the Bodhidharma statue, as shown in Fig. 2) may have transformed from emerald green. The thickness of the pigment layer in D1-18 L1 is $80 \mu \mathrm{m}$, and its mineral phase was almost completely transformed into blue-green lavendulan, while the emerald green pigment layer D1-15 L1, with a thickness of $570 \mu \mathrm{m}$ has no sign of alteration. This observation suggests that the transformation of emerald green pigment depends on the thickness of the pigment layer, with thinner pigment layers exhibiting lavendulan. This could be because the thinner the pigment layer, the easier it is to contact with the moisture and acid substances in the air, and the easier it is for the soluble salt ions to migrate in the pigment layer, accelerating the transformation of emerald green to lavendulan.

\section{Black pigment layers}

There are 4 layers of black pigment layers: D1-11 L1, D1-12 L2, D1-18 L2 and D1-19 L1. The Raman spectra of the black pigment shows two broad bands near $1325 \mathrm{~cm}^{-1}$ and $1580 \mathrm{~cm}^{-1}$ (Fig. $10 \mathrm{i}$ ), which is consistent with the standard Raman spectra of lamp black (C). The black pigment appears gelatinous under the microscope, and has no granular sensation (Fig. 4 a). Therefore, it can be inferred that the black pigment is the Chinese ink, which the most commonly used black pigment in ancient China.

\section{Rose red painted layer}


The rose red painted layers are only distributed in the bottom step area of the statue pedestal in sample D1-16. From the preserved photos [29], this area was originally reddish brown before restoration and protection in 1981, and the painted layer was largely peeled off (see Fig. 11 a). According to the interview with the staff of Lingyan Temple, the rose red area was painted in the restoration and protection of the Arhat statue in 1981; in addition, a layer of varnish was also painted in the bottom step area of pedestal in order to isolate moisture[1].

EDS analysis shows that the mass percentage of $\mathrm{C}$ and $\mathrm{O}$ elements in D1-16 L1 is more than 75\% consistent with an organic pigment. The characteristic bands in the Raman spectrum (Fig. 12 b) near 618, 732, 1000, 1233, 1283, 1361, 1493, 1547, $1595 \mathrm{~cm}^{-1}$ match the Rhodamine $\mathrm{B}\left(\mathrm{C}_{28} \mathrm{H}_{31} \mathrm{ClN}_{2} \mathrm{O}_{3}\right)$ [30]. The white priming layer of D1-16 L2 mainly contains $\mathrm{Ti}$, Ca and $\mathrm{S}$. Raman analysis confirms that the layer contains anatase titan white $\left(\mathrm{TiO}_{2}\right.$, Fig. $\left.12 \mathrm{c}\right)$. The infrared spectrum of the D1-16 was shown in Fig. 12 d, in which the absorption bands around 3538, $3405 \mathrm{~cm}^{-1}$ and 1685, $1621 \mathrm{~cm}^{-1}$ correspond to the stretching and bending vibration of water; the absorption bands around $1141,1115 \mathrm{~cm}^{-1}$ correspond to the symmetric and asymmetric stretching vibration of $\left(\mathrm{SO}_{4}\right)^{2-}$, and the bands around $671,602 \mathrm{~cm}^{-1}$ correspond to the bending vibration of $\left(\mathrm{SO}_{4}\right)^{2-}$. The characteristic bands correspond to the infrared characteristic absorption bands of gypsum $\left(\mathrm{CaSO}_{4} \cdot 2 \mathrm{H}_{2} \mathrm{O}\right)[31]$. D1-16 L3 appears brown-black, and the content of $\mathrm{C}$ and $\mathrm{O}$ elements in this layer is more than $85 \%$, which should be some kind of organic matter. The infrared spectrum of D1-16, in addition to the characteristic absorption bands of gypsum, exhibits bands in the vicinity of 2926, 2855, 1581, 1385 (Symmetrically deformed vibration of dimethyl in bisphenol A), 1456, 1305 (stretching vibration of fatty aromatic ether $\mathrm{C} \varangle \mathrm{O}$ ), 913 (stretch vibration of epoxy ring $\mathrm{C} \otimes 0$ ) $\mathrm{cm}^{-1}$, etc. These bands basically match with the infrared characteristic bands of an epoxy resin [32], so it can be inferred that L3 was coated with epoxy resin on the bottom step of pedestal for moisture insulation in the previous restoration. Raman analysis shows that the orange - red mineral pigment in $\mathrm{L} 4$ is ochre $\left(\mathrm{Fe}_{2} \mathrm{O}_{3}\right)$.

The determination of the mineral composition of the outermost pigment layers may also provide a basis for the estimation of the time of the application of the latest paint of the Bodhidharma statue. According to the results of Raman analysis, the yellow pigment layer L1 of D1-14 contains lead chrome yellow and chalk, and the green pigment L2 is emerald green. The L1 yellow pigment layer is the floral motif painted over the green pigment layer. It can be seen from the cross sections that there is no priming layer between the yellow pigment layer and the green pigment layer, indicating that the two layers of pigment were painted on the surface of the statue at the same time. Chrome yellow appeared in the early $19^{\text {th }}$ century [33, 34], emerald green (chemical name "copper acetoarsenit"), was first synthesized in Germany in 1814, mainly used in the 1830 s and early $20^{\text {th }}$ century [35]. The use of lead chrome yellow and emerald green in the outermost pigment layer confirms that the statue was repainted later than 1814. Chinese scholars' textual research on the existing inscriptions and other materials in Lingyan Temple has unanimously concluded that the last polychrome of the arhat statues of Lingyan Temple was in the thirteenth year of the reign of Tongzhi (1874CE) [2, 36] in the Qing Dynasty(1639-1912 CE). Lead chrome yellow and emerald green were most likely painted on the surface of the statue in the 1874 redecoration. The use of anatase titan white pigment in D1-3 pink pigment layer and D1-16 L2 indicated that the statue had also been treated after 1874, because the commercial titanium dioxide pigment appeared in 1916 [37]. There is no mention of the polychrome repainting of the arhat statues in Lingyan Temple after 1874 in various Chinese documents. From the photographs taken before the restoration of the Bodhidharma statue in 1981 (Fig. 11 a), it can be seen that the state of the pink area from D1-3 (the inside of the hat) before 1981 is similar to its current condition. Based on the use time of anatase titan white, it can be inferred that the pink area containing anatase titan white should has been painted between 1920 s to the 1980s. In addition, the Bodhidharma statue was painted with a rose red organic pigment on the previously reddishbrown step area. In summary, the most recent large-scale repainting of the statue took place in 1874, and there have been at least two partial repainting treatments since then.

\section{Conclusions}


Based on the scientific analysis of the painted layers of Lingyan Temple's Bodhidharma Statue, there are some insights.

The statue has been painted at least eight times and there have been at least two partial repainting treatments in the $20^{\text {th }}$ C. Before each new polychrome white wash was applied over the last pigment layer. In the most recent polychrome, a new technique of pasting white paper on the clay figure surface and then painting the priming layer and the pigment layer was used in some areas.

The gold layer in the gilding decoration area mostly uses gold foil with a high content of gold, and its thickness is only 1-2 $\mu \mathrm{m}$. In different periods of history, silver foil and gold mixed with golden yellow mineral pigments were used to replace the original gold foil layers in the gilding area. The priming layers material used in the each previous polychrome of the statue was mostly white kaolin or a mixture of other white minerals based on kaolin as the matrix. Sometimes lead white, chalk or a mineral mixture of the two white pigments were used as the priming layers material. In addition, the clay with a low aluminum and high iron content has been used as priming layers material in the most recent polychrome.

The pigment layers of the statue was mostly composed of a single inorganic mineral, and the individual pigment layers were made of 2-3 kinds of minerals to achieve different colors. The red series mineral pigments used in the statue are cinnabar $(\mathrm{HgS})$, hematite $\left(\mathrm{Fe}_{2} \mathrm{O}_{3}\right)$ and red lead $\left(\mathrm{Pb}_{3} \mathrm{O}_{4}\right)$; Yellow pigments includes orpiment $\left(\mathrm{As}_{2} \mathrm{~S}_{3}\right)$ and lead chrome yellow $\left(\mathrm{PbCrO}_{4}\right)$; White pigments includes lead white $\left(2 \mathrm{PbCO}_{3} \cdot \mathrm{Pb}(\mathrm{OH})_{2}\right)$, chalk $\left(\mathrm{CaCO}_{3}\right)$ and magnesite $\left(\mathrm{MgCO}_{3}\right)$; $\mathrm{Blue}$ pigments includes azurite $\left(\mathrm{Cu}_{3}\left(\mathrm{CO}_{3}\right)_{2}(\mathrm{OH})_{2}\right)$ and artificial ultramarine $\left(\mathrm{Na}_{6-10} \mathrm{Al}_{6} \mathrm{Si}_{6} \mathrm{O}_{24} \mathrm{~S}_{2-4}\right)$; Green pigments includes $19^{\text {th }}$ C. emerald green $\left(\mathrm{Cu}\left(\mathrm{C}_{2} \mathrm{H}_{3} \mathrm{O}_{2}\right)_{2} \cdot 3 \mathrm{Cu}\left(\mathrm{AsO}_{2}\right)_{2}\right)$ and copper-containing pigments in a glassy state; Black pigments were only lamp black (C). In addition, organic pigments and anatase titan white $\left(\mathrm{TiO}_{2}\right)$ has been used in partial repainting more recently. The blue-green lavendulan mineral on the surface of the statue is not intended to be used as a blue-green pigment, but rather is a degradation product of emerald green pigment. The transformation of emerald green pigment seems related to the thickness of the pigment layer. The thinner the pigment layer, the easier it is to transform.

Based on the scientific analysis, a new understanding of the structure, material, technology and other aspects of the painted layers of Bodhidharma statue were formed. There are still open questions related to the identity of the green copper-containing pigments in glassy state? What kind of technology and materials were used in ancient China to make this kind of pigment? In addition, the determination of organic materials such as the oily substance covering the face and neck of Bodhidharma statue, the adhesive materials used to apply the gold foil in the gilding paint layers, and the pigment binder are also crucial for our original intention. Further research is needed to identify binders, further investigate technology and identify the source of the chloride ions which have led to the degradation of silver and arsenic based pigments.

\section{Abbreviations}

OM: Optical microscopy; SEM-EDS: Scanning electron microscopy coupled with energy dispersive X-ray analysis; FTIR: Fourier transform infrared spectroscopy.

\section{Declarations}

\section{Acknowledgements}

The authors would like to express their great gratitude to Prof.Chuanchang Wang, Mr.Yunpeng Wang and Ms.Fangzhi Liu, etc, from the Shandong Cultural Relics Conservation and Restoration Center for their help in analysis.

\section{Authors' contributions}


QM provided support and guidance for this study. YT performed experiments analysis and drafted the manuscript. YC and XW provided the samples and assistance in the study. YT and ZL took samples. AN made revisions to the paper. All authors read and approved the final manuscript.

\section{Funding}

The research was financially supported by Protection and Restoration Project of Part of Arhat Statues in Thousand Buddha Hall of Lingyan Temple in Changqing, Shandong (Phase I)(1-02-18-3700-013).

\section{Availability of data and materials}

The datasets used during this study are available from the corresponding author on request.

\section{Competing interests}

The authors declare that they have no competing interests.

\section{Author details}

${ }^{1}$ Institute of Cultural Heritage and History of Science \& Technology, University of Science and Technology Beijing, Beijing 100083, China. ${ }^{2}$ Shandong Cultural Relic Conservation and Restoration Center, Jinan 250014, Shandong Province, China.

${ }^{3}$ International Joint Research Laboratory of Environmental and Social Archaeology, Shandong University, Qingdao 266237, Shandong, China. ${ }^{4}$ Courtauld Institute of Art, Somerset House, Strand, WC2R ORN, London, UK.

\section{References}

1. Hu JG. Coloured sculpture restoration in Lingyan Temple in Changqing, Shangdong. Archaeology. 1983;(11):1025】 1038.https://doi.org/cnki:sun:kagu.0.1983-11-014.

2. Zhou FS. Date of manufacture and related issues about Arhat sculpture in Lingyan Temple in Changqing, Shangdong. Cultural Relics. 1984;(3):76ه82.https://doi.org/10.13619/j.cnki. cn11-1532/k.1984.03.016.

3. Wang CC, Li ZhM, Wang XN, Ma QL. Scientific study of the Song Dynasty polychrome Arhat statues from the Magic Cliff Monastery in Jinan. Sciences of Conservation and Archaeology. 2018;30(06):37-

47.https://doi.org/10.16334/j.cnki.cn31-1652/k.2018.06.006.

4. Lang PL, Keefer CD, Juenemann JC, Tran KV, Peters SM, Huth NM, Joyaux AG. The infrared microspectroscopic and energy dispersive X-ray analysis of paints removed from a painted, medieval sculpture of Saint Wolfgang. Microchemical Journal. 2003;74(1):33-46. https://doi.org/10.1016/S0026-265X(02)00101-7.

5. Franquelo ML, Duran A, Castaing J, Arquillo D, Perez-Rodriguez JL. XRF, $\mu$-XRD and $\mu$-spectroscopic techniques for revealing the composition and structure of paint layers on polychrome sculptures after multiple restorations. Talanta. 2012;89(1):462-469.https://doi.org/10.1016/j.talanta.2011.12.063.

6. Egel E, Simon S. Investigation of the painting materials in Zhongshan Grottoes (Shaanxi, China). herit sci 1, 29 (2013).https://doi.org/10.1186/2050-7445-1-29.

7. Wang N, He L, Egel E, Simon S, Rong B. Complementary analytical methods in identifying gilding and painting techniques of ancient clay-based polychromic sculptures. Microchemical Journal. 2014;114(5):125140.https://doi.org/10.1016/j.microc.2013.12.011.

8. Hu KJ, Bai ChB, Ma LY, Bai K, Liu DB, Fan BB. A study on the painting techniques and materials of the murals in the Five Northern Provinces'Assembly Hall, Ziyang, China. herit sci 1, 18 (2013). https://doi.org/10.1186/2050-7445-1-18.

9. Mahmoud HHM. Investigations by Raman microscopy, ESEM and FTIR-ATR of wall paintings from Qasr el-Ghuieta temple, Kharga Oasis, Egypt. herit sci 2, 18 (2014). https://doi.org/10.1186/s40494-014-0018-x. 
10. Li ZM, Wang, LL, Ma, QL, Mei JJ. A scientific study of the pigments in the wall paintings at Jokhang Monastery in Lhasa, Tibet, China. herit sci 2, 21 (2014).https://doi.org/10.1186/s40494-014-0021-2.

11. Fiorillo F, Fiorentino S, Montanari M, Monaco CR, Bianco AD, Vandini M. Learning from the past, intervening in the present: the role of conservation science in the challenging restoration of the wall painting Marriage at Cana by Luca Longhi (Ravenna, Italy). herit Sci 8, 10 (2020). https://doi.org/10.1186/s40494-020-0354-y.

12. Wei SY, Ma QL, Schreiner M. Scientific investigation of the paint and adhesive materials used in the Western Han dynasty polychromy terracotta army, Qingzhou, China. Journal of Archaeological Science. 2012;39(5):16281633.https://doi.org/10.1016/j.jas.2012.01.011.

13. Rosado L, Pevenage JV, Vandenabeele P, Candeias A, LopesMdC, Tavares D, Alfenim R, Schiavon N, Mirão J. Multianalytical study of ceramic pigments application in the study of Iron Age decorated pottery from SW Iberia. Measurement. 2018;118(3):262-274.https://doi.org/10.1016/j.measurement.2017.05.016.

14. Li XH, Jiang XP, Chen C, Tu N. Research on Diffuse Reflectance Infrared Fourier Transform Spectroscopy of Kinds of Kaolin in Various Areas. Spectroscopy and Spectral Analysis. 2011;31(01):114118.https://doi.org/10.3964/j.issn.1000-0593(2011)01-0114-05.

15. Bell IM, Clark RJH, Gibbs PJ. Raman spectroscopic library of natural and synthetic pigments (pre- $\approx 1850$ AD). Spectrochimica Acta Part A: Molecular and Biomolecular Spectroscopy. 1997;53(12): 21592179.https://doi.org/10.1016/S1386-1425(97)00140-6.

16. Burgio L, Clark RJH. Library of FT-Raman spectra of pigments, minerals, pigment media and varnishes, and supplement to existing library of Raman spectra of pigments with visible excitation. Spectrochim Acta A. 2001;57(7):1491-521.https://doi.org/10.1016/S1386-1425(00)00495-9.

17. Li ZX, Fan ZX, Sheng FL. New Developments in the Research of Colour changes in Red Lead Vermilion and Hematite. Dunhuang Research. 1992;(01):89-117+123-124+85.https://doi.org/10.13584/j.cnki.issn10004106.1992.01.013.

18. Li ZX. A Study on the Red Pigments Used in the Mogao Frescoes and Mechanism of their Discolouration.Dunhuang Research. 1992;(03):41-54+128-129.https://doi.org/10.13584/j.cnki. issn1000-4106.1992.03.014.

19. Ma QL, Hu ZhD, Li ZX. Corrosion and harm of microorganisms to Frescoes pigment.Dunhuang Research. 1996; (03):136-144.https://doi.org/10.13584/j.cnki.issn1000-4106. 1996.03.014.

20. Aceto M, Gatti G, Agostino A, Fenoglio G, Giordano V, et al. The mural paintings of Ala di Stura (Piedmont, Italy) : a hidden treasure investigated. Journal of Raman Spectroscopy, 2012;43 (11):17541760.https://doi.org/10.1002/jrs.4066.

21. Giester G, Kolitsch U, Leverett P, Turner P, Williams P. The crystal structures of lavendulan, sampleite, and a new polymorph of sampleite. Eur J Mineral. 2007;19(1):75-93.http://dx.doi.org/10.1127/0935-1221/2007/0019-0075.

22. ONDRUŠ P, Veselovský F, Skála F, SEJKORA J, Pažout R, Frýda J, Gabašová A, Vajdak J. Lemanskiite, $\mathrm{NaCaCu}\left(\mathrm{AsO}_{4}\right)_{4} \mathrm{Cl} \otimes 5 \mathrm{H}_{2} \mathrm{O}$, a new mineral species from the Abundancia mine, Chile. The Canadian Mineralogist. 2006;44(2):523-531.https://doi.org/10.2113/gscanmin.44.2.523.

23. Frost R L, Weier M L, Williams P A, Leverett P, Kloprogge J, Theo Kloprogge J. Raman spectroscopy of the sampleite group of minerals. Journal of Raman Spectroscopy.2007;38(5):574-83.https://doi.org/10.1002/jrs.1702.

24. Chen XL, Yang Q. Micro-Raman spectroscopy study of three green pigments containing copper and arsenic. Sciences of conservation and archaeology. 2015;27(3):84-9.https://doi.org/10.16334/j.cnki.cn31-1652/k.2015.03.015.

25. Chen EX, Zhang BJ, Zhao F. Comprehensive analysis of polychrome grotto relics: a case study of the paint layers from anyue, sichuan, china. Analytical letters. 2020;53(9):1455-71.https://doi.org/10.1080/00032719.2019.1709197.

26. Wang LQ, Ma YN, Zhang YX, Zhao X, He QJ, Guo JY, Ren HT.Pigment Identification of Sleeping Buddha at World Cultural Heritage Dazu Rock Carvings With $\mu$-Raman Spectroscopy and Related Research.Spectroscopy and Spectral Analysis. 2020;40(10):3199-3204.https://doi.org/10.3964/j.issn.1000-0593(2020)10-3199-06. 
27. Cui Q, Zhang YX, Shui BW, Yu ZR, Fan ZX, Shan ZW, Chen XY, Su BM. Study of copper and arsenic \containing green and blue $\llbracket$ green pigments of rock carvings at Big Buddha Bay in Dazu. Sciences of conservation and archaeology. 2020;32(06):87-94. https://doi.org/10.16334/j.cnki.cn31-1652/k.20180601236.

28. Li ZM, Wang LL, Chen HL, Ma QL. Degradation of emerald green: scientifc studieson multi-polychrome Vairocana Statue in Dazu Rock Carvings, Chongqing, China. herit Sci 8, 64 (2020). https://doi.org/10.1186/s40494-020-00410-2.

29. Zhang YH. Lingyan temple in shandong province. Jinan: Shandong people's publishing house, 1983: 63.

30. Ma Y, Hu W, Song XN, Wang ChK. Density Functional Theory Study on Raman Spectra of Rhodamine Molecules in Different Forms. Chinese Journal of chemical Physics. 2014;27(03):291-296.https://doi.org/10.1063/16740068/27/03/291-296.

31. Bao YS, Yang YY, Wang S,Bian J, Yu Y, Meng XS. Differences of Material Base of Gypsum Before and After Processing Drugs by IR Spectroscopy and ICP-MS. Chinese Journal of Spectroscopy Laboratory. 2012;29(05):31933197.https://doi.org/10.3969/j.issn.1004-8138.2012.05.132.

32. Zhao J. Study on key analytical technology of bisphenol A epoxy resin system. Qingdao University of Science and technology, 2016.

33. Kühn H, Curran M. Chrome yellow and other chromate pigments. In: Feller RL, editor. Artists'pigments: a handbook of their history and characteristics, vol. 1. London: Cambridge University Press, 1986:187-204.

34. Geldof M, van der Werf I.D, Haswell R. The examination of Van Gogh's chrome yellow pigments in'Field with Irises near Arles' using quantitative SEM-WDX. herit Sci 7, 100 (2019). https://doi.org/10.1186/s40494-019-0341-3.

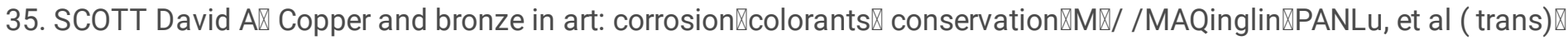
Beijing: Science Press $₫ 2009:$ 270囚273》

36. Zhang YH. Textual research on the ancient statue of lingyan temple in changqing. Cultural Relics. 1959;(12):117.https://doi.org/10.13619/j.cnki.cn11-1532/k.1959.12.022.

37. WaltonR.E.Titanium Dioxide Pigments. In: Surface Coatings. Springer, Dordrecht. 1993;(01)435448.https://doi.org/10.1007/978-94-011-1220-8_26.

\section{Figures}



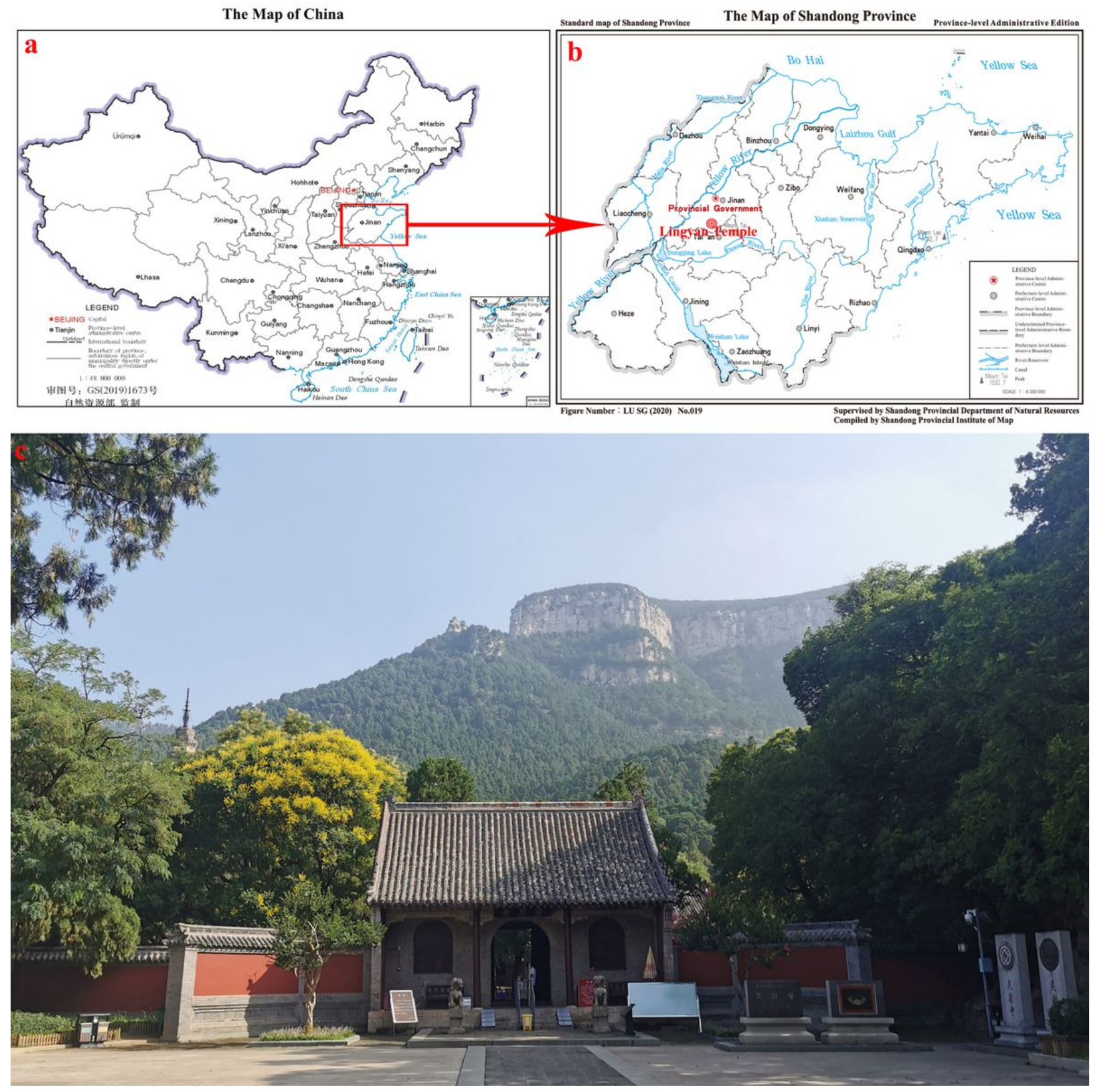

Figure 1

(a) The Location of Shandong Province within China, (b) The location of Lingyan Temple in Shandong Province, (c) Exterior view of Lingyan Temple 


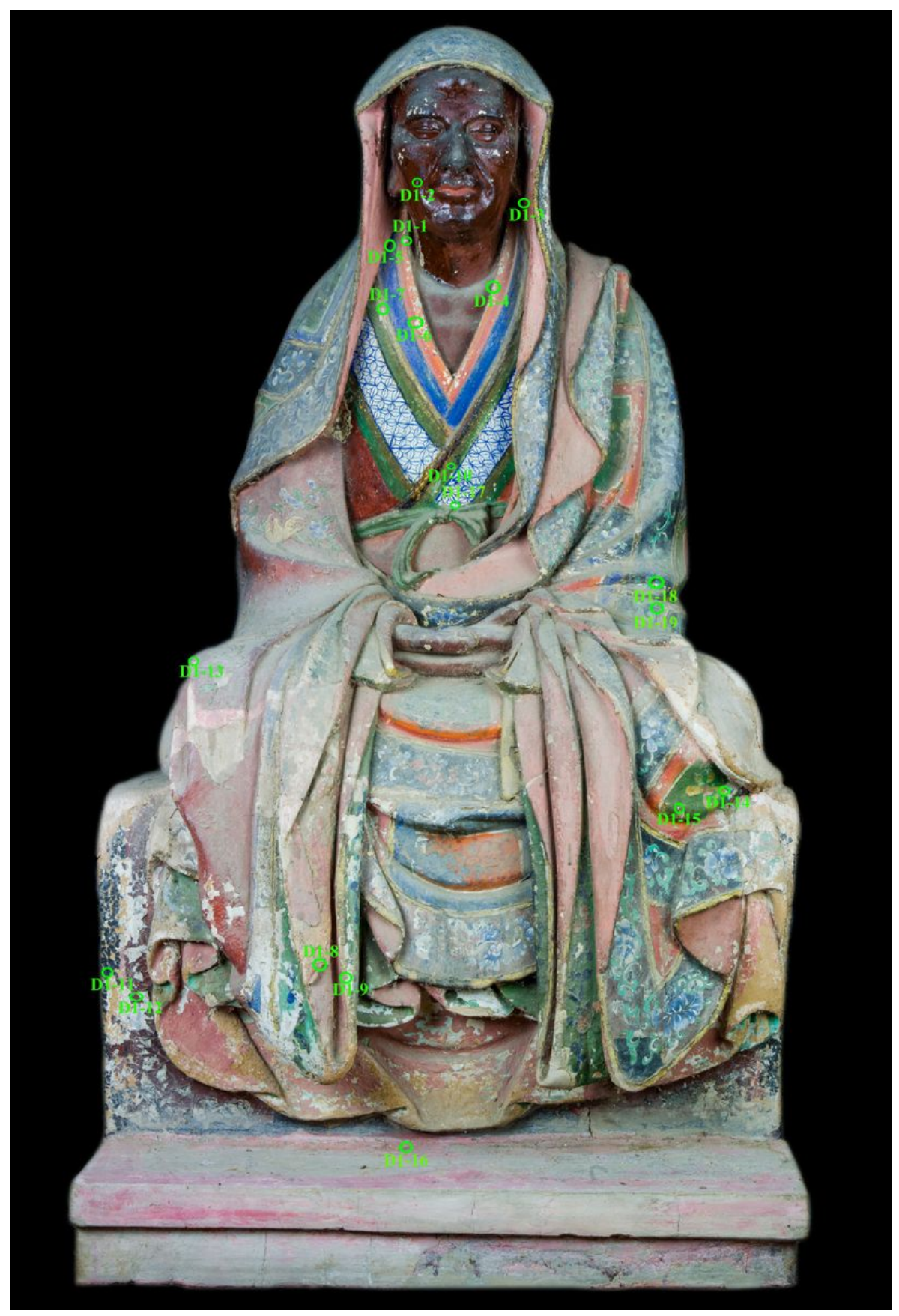

Figure 2

The statue of Bodhidharma, Lingyan Temple. Location of sampling positions 

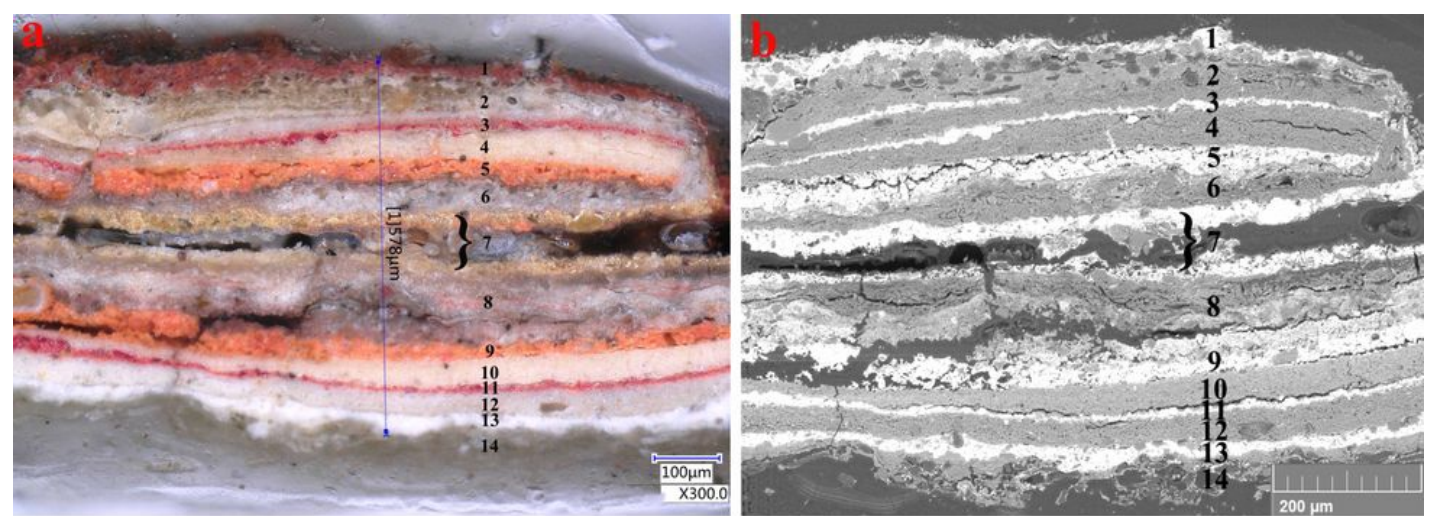

\section{D1-1}

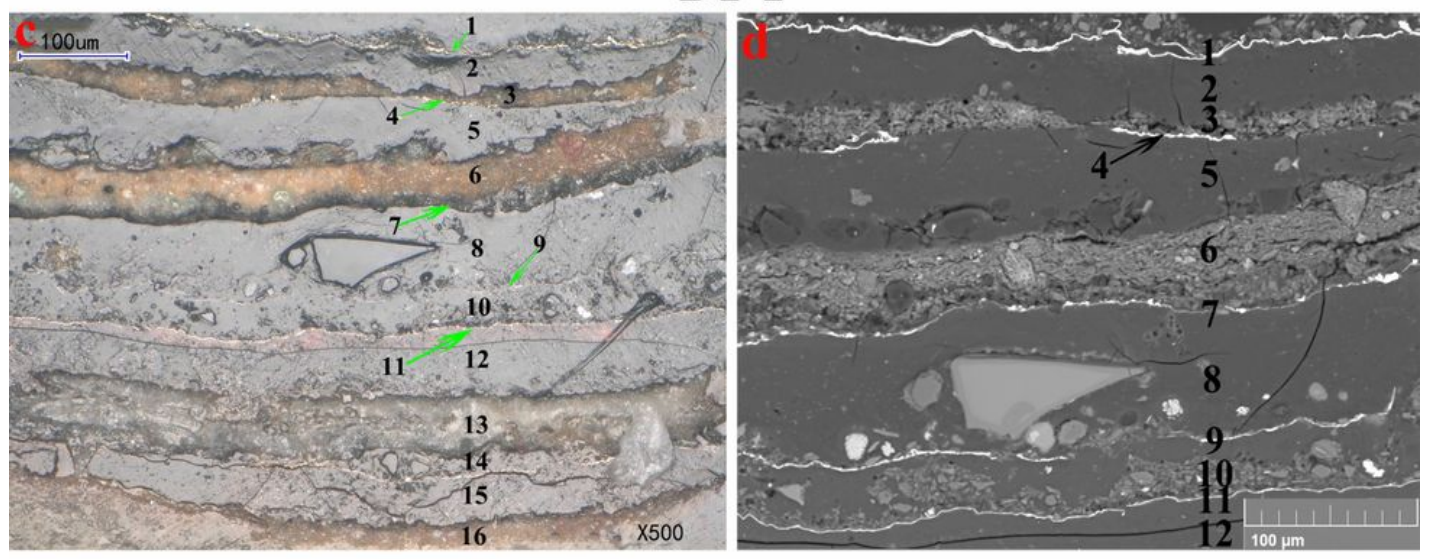

\section{D1-7}

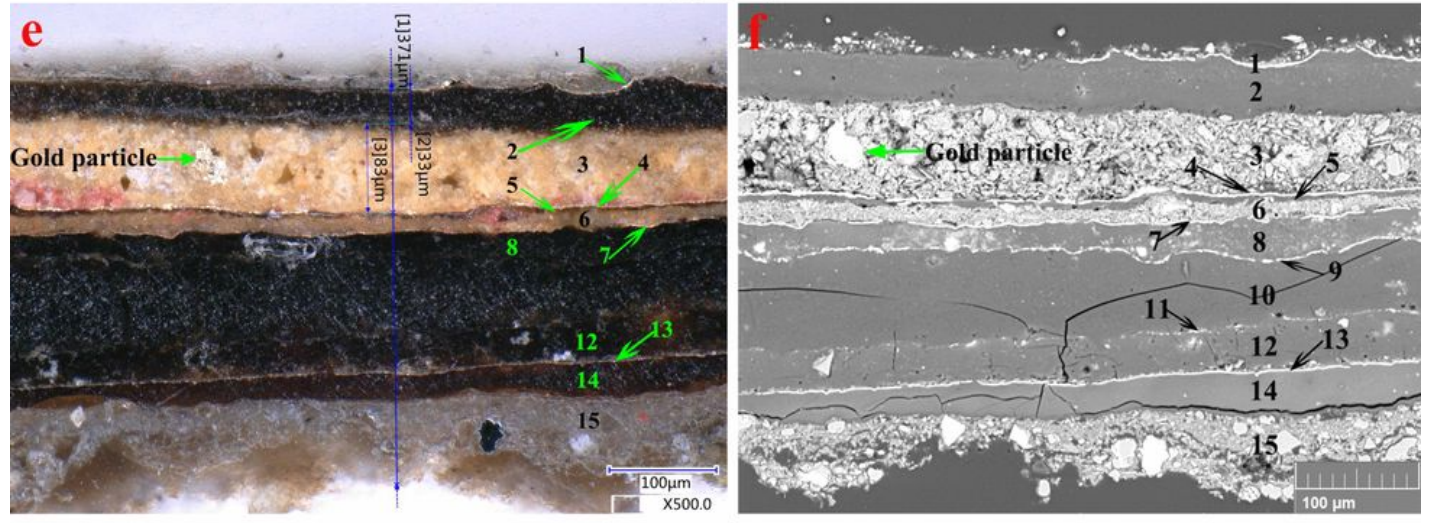

D1-9

\section{Figure 3}

Comparison of cross-sections in visible light and backscattered electron images. (a) and (e) the micrograph under annular (dark field) light source, (c) the micrograph under a coaxial (bright light) source, (b), (d), (f) the backscattered electron images. The numerals in the figure are in order of different layers startingfrom the surface of statue to the unpainted clay idol. 

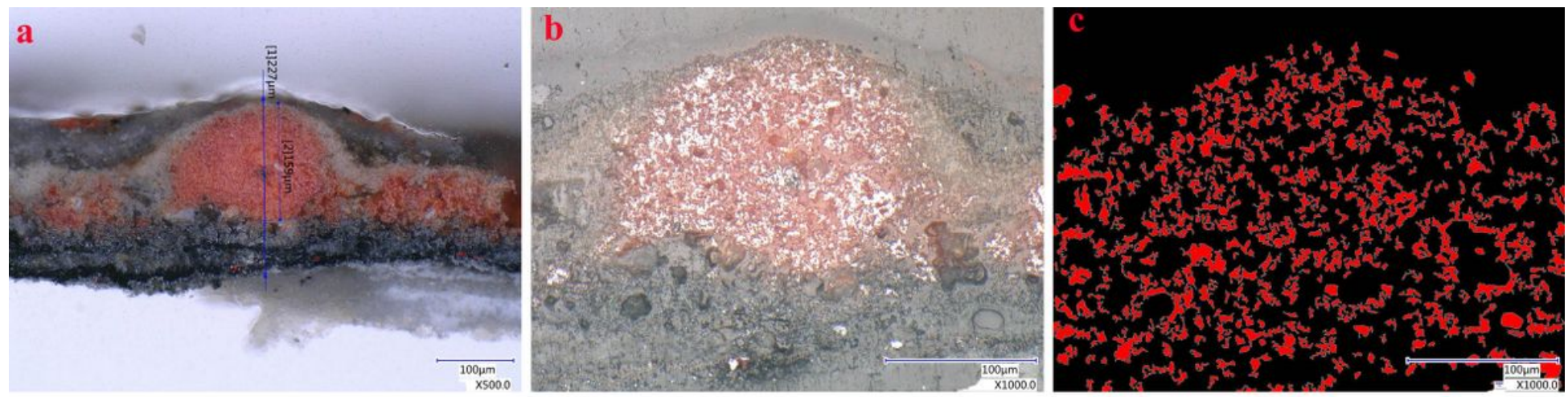

\section{D1-12}
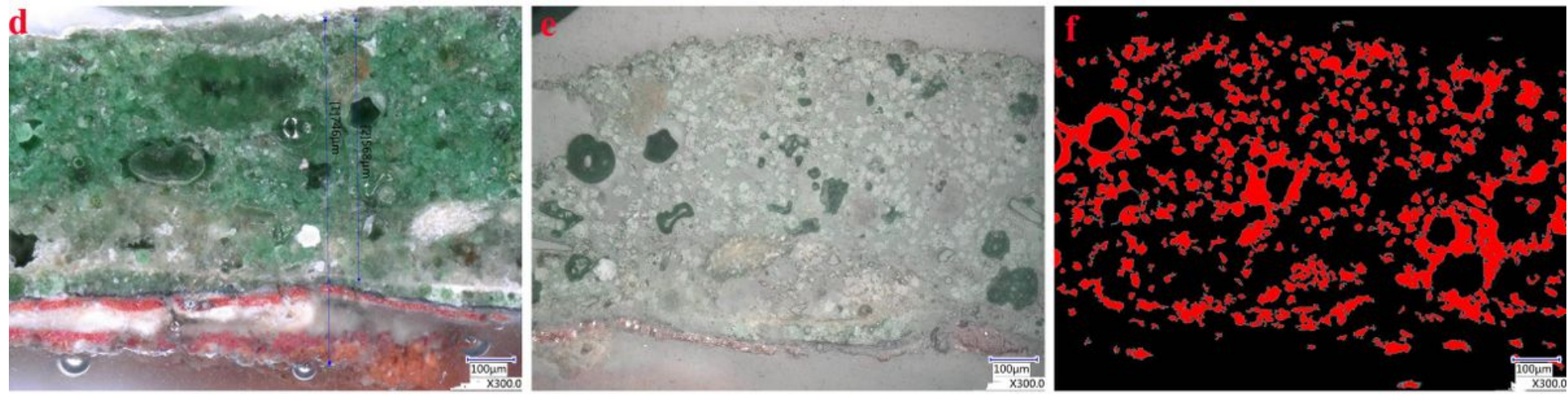

D1-15

\section{Figure 4}

(a) and (d) micrographs of cross-sections under the annular (dark field) light source, (b) and (e) the cross-section micrographs of the paint layers in coaxial (bright field) illumination (c) and (f) the pigment particle distribution maps were fitted by the micrographs under coaxial light source 


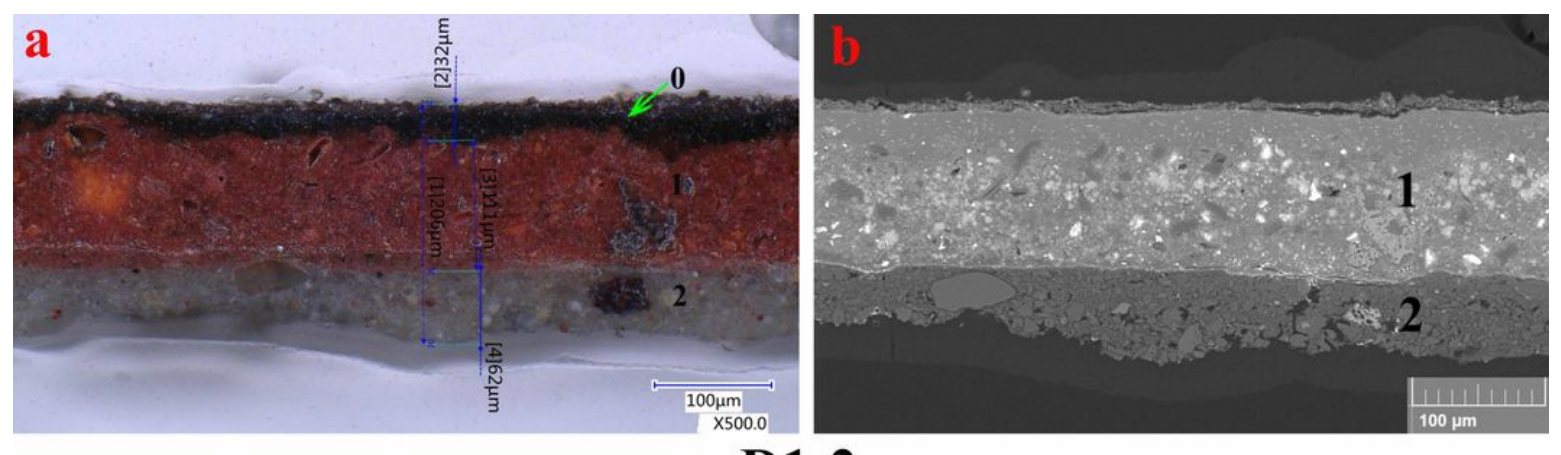

D1-2

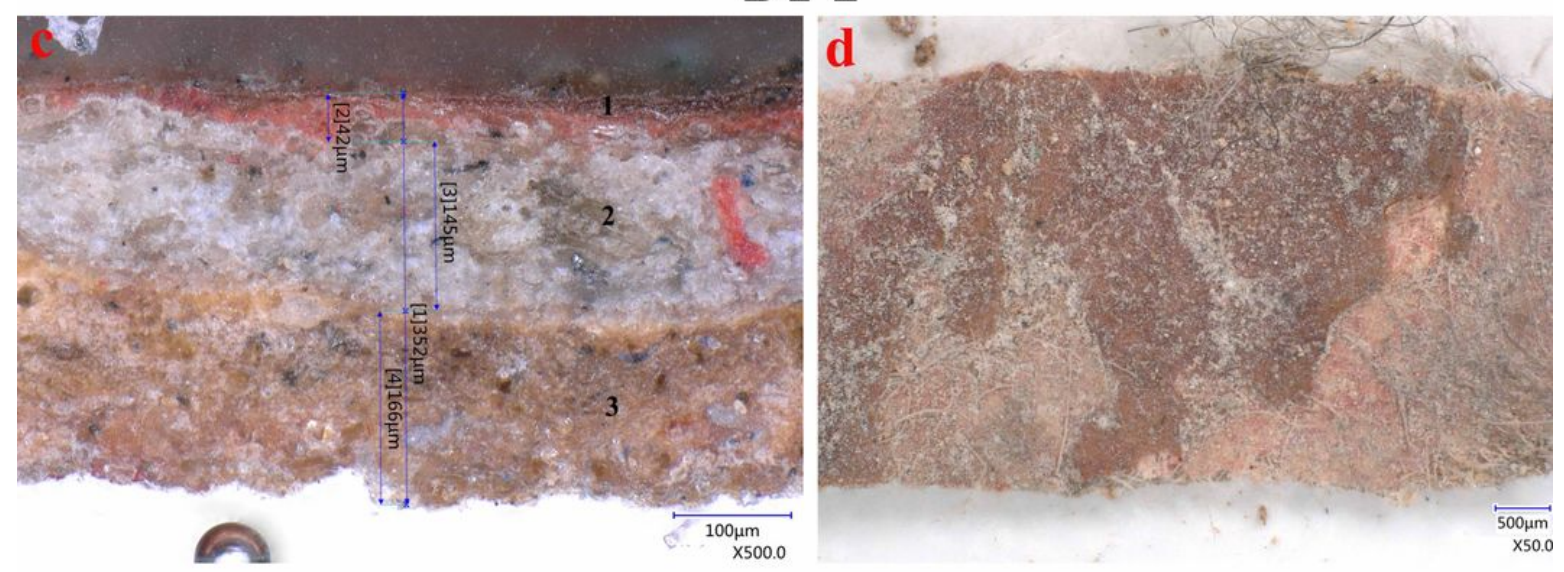

\section{D1-8}

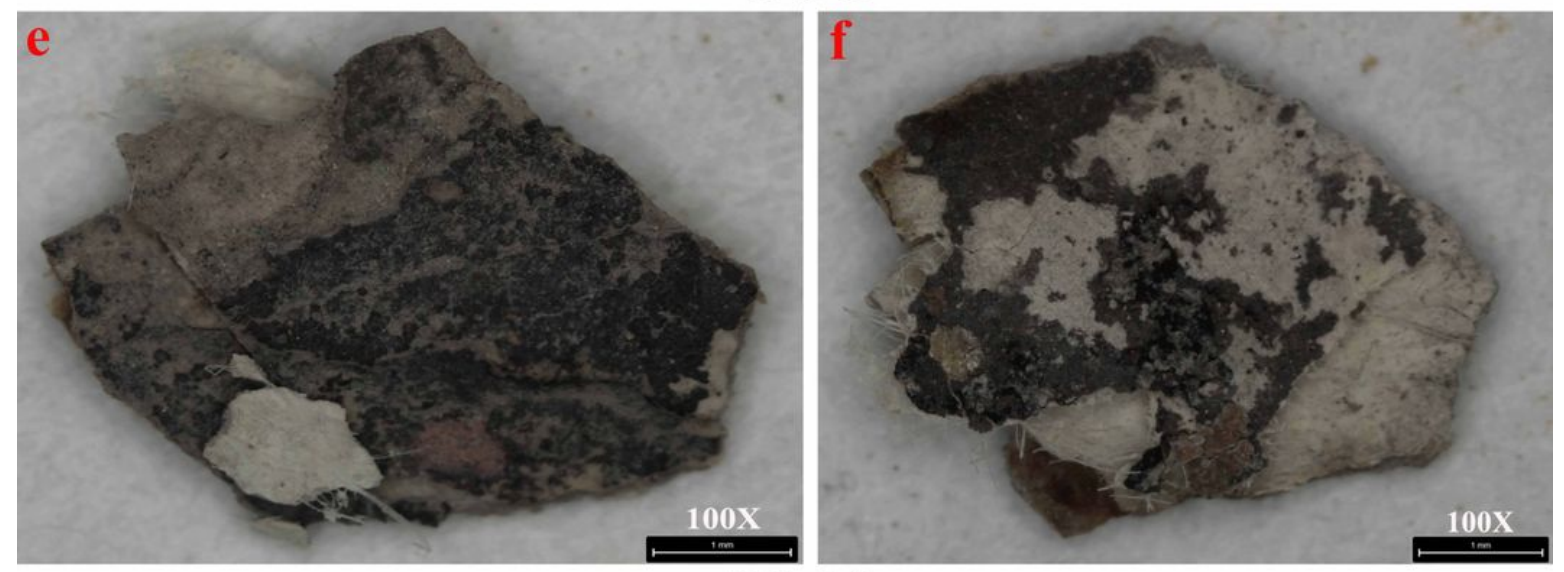

\section{D1-19}

\section{Figure 5}

(a) and (c) the micrographs of the D1-2 and D1-8, (b) the cross-section seen in backscattered electron images of the D1-2,

(d) and (f) images of fragments prior to embedding showing paper fibers attached to the back of the paint layers, (e) the front of the fragment 


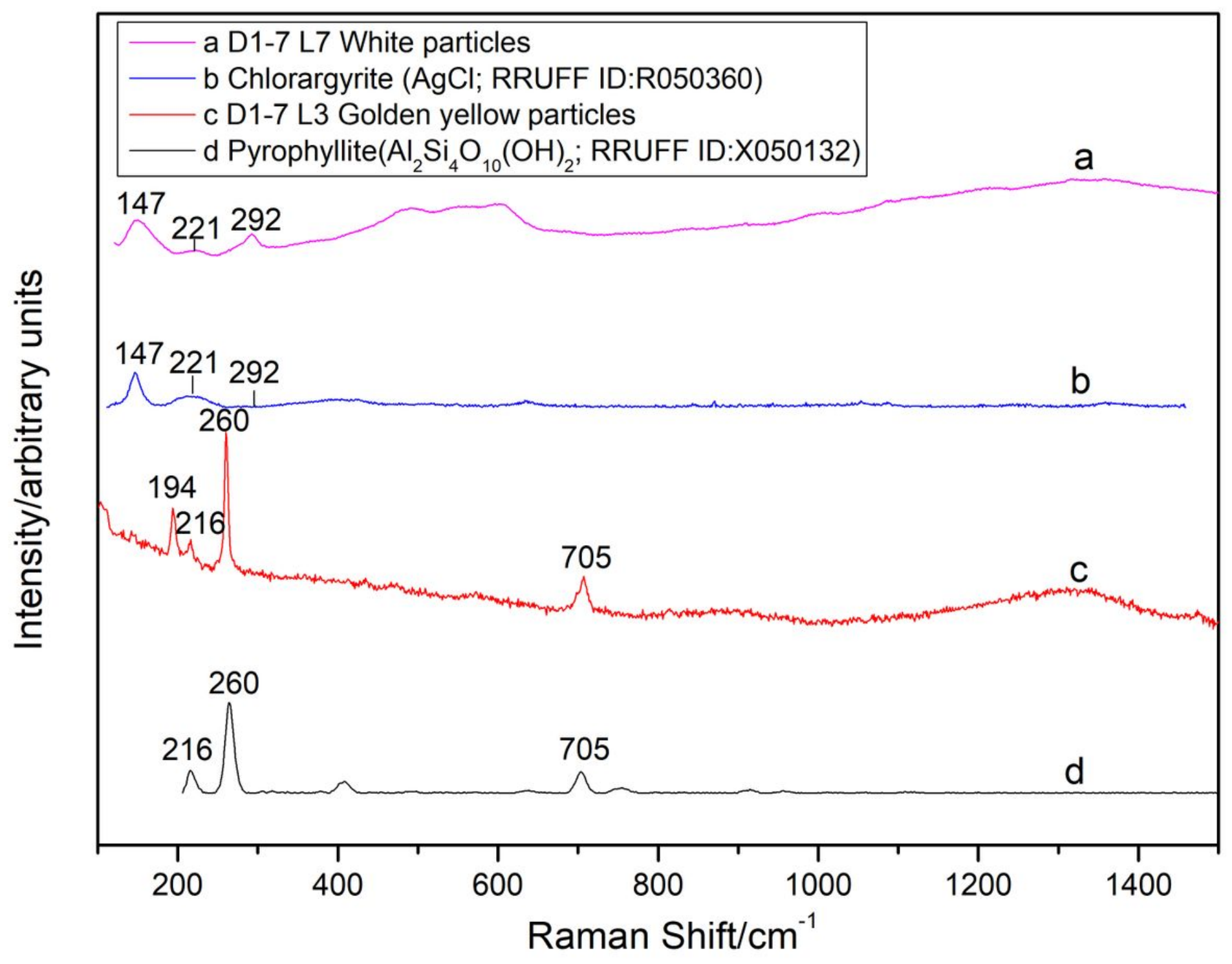

Figure 6

(a) and (c) Raman spectrum of D1-7 L7 white particles and L3 golden yellow particles, (b) and (d) Raman spectrum of chlorargyrite and pyrophyllite from the RRUFF open source database 


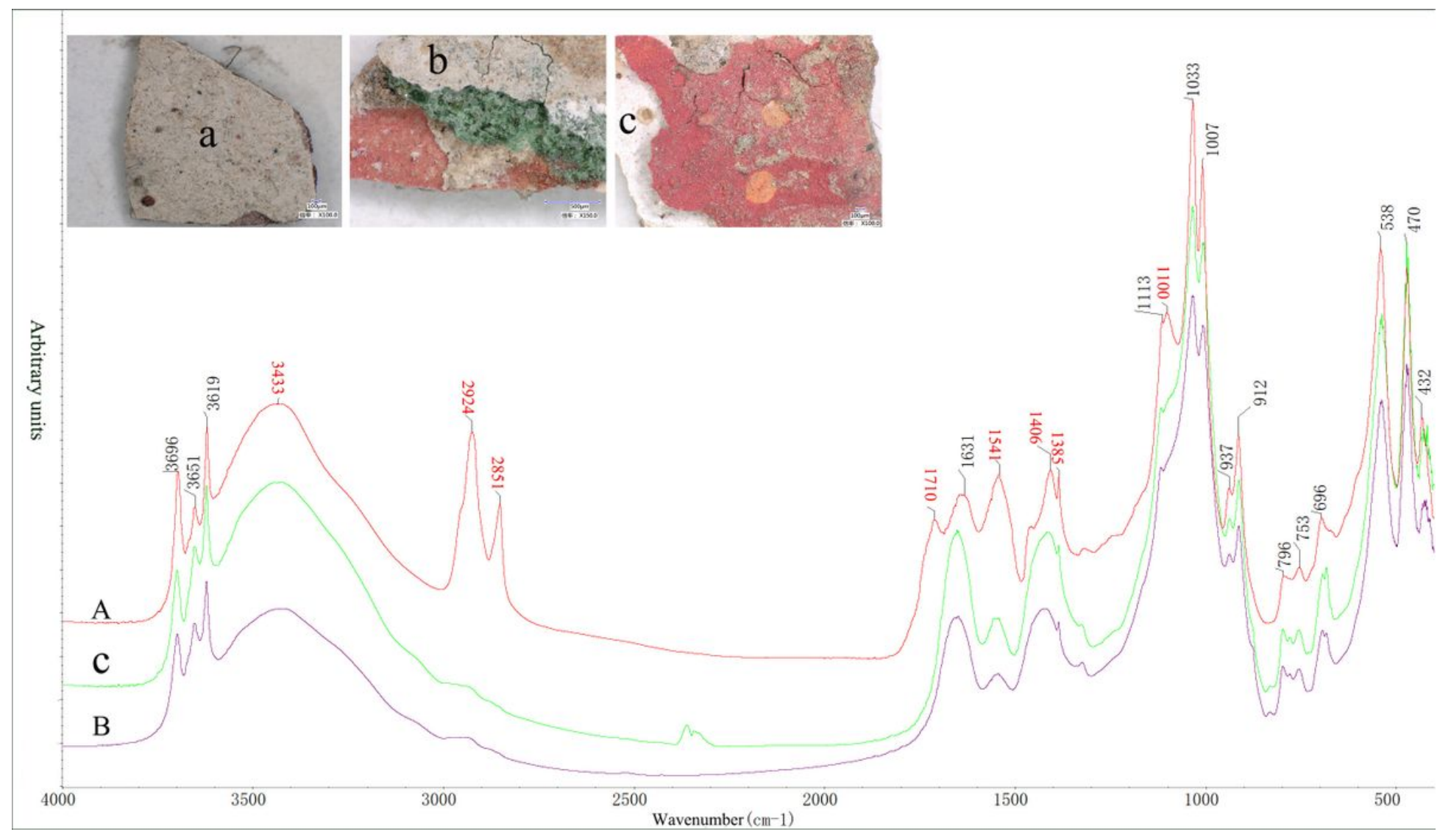

\section{Figure 7}

(a), (b) and (c) the back or exposed white priming layer of D1-2, D1-5, D1-6 before samples were embedded respectively; A, $\mathrm{B}$ and $\mathrm{C}$ correspond to the infrared spectra of the three samples respectively

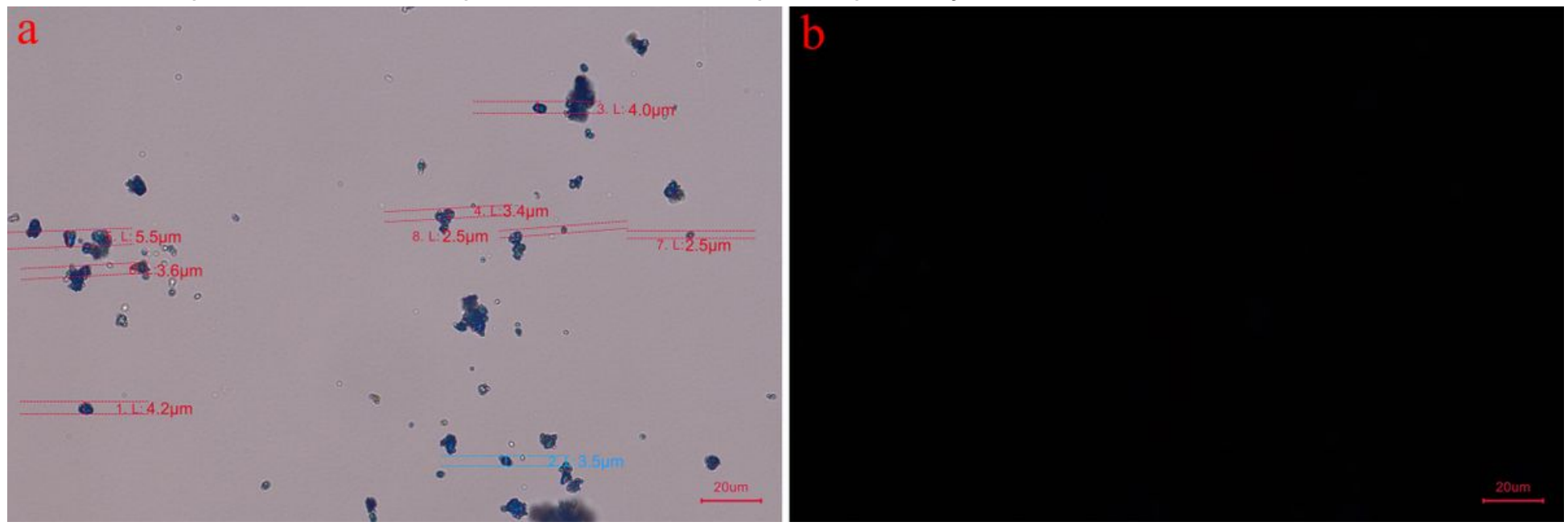

Figure 8

Polarized photomicrograph of D1-10 L1 ultramarine pigments, (a) plane polarized light, (b) orthogonal polarized light 


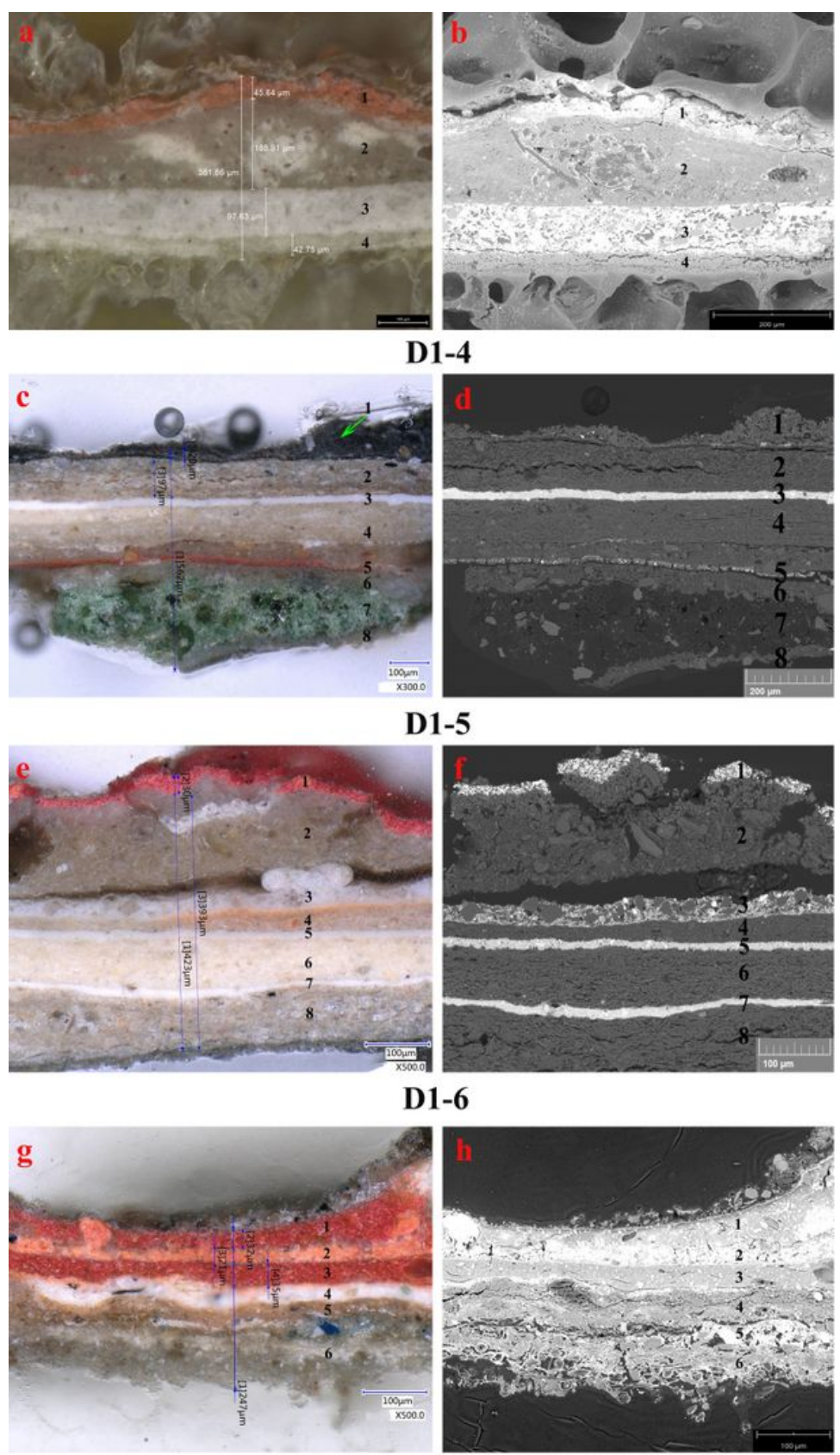

D1-13
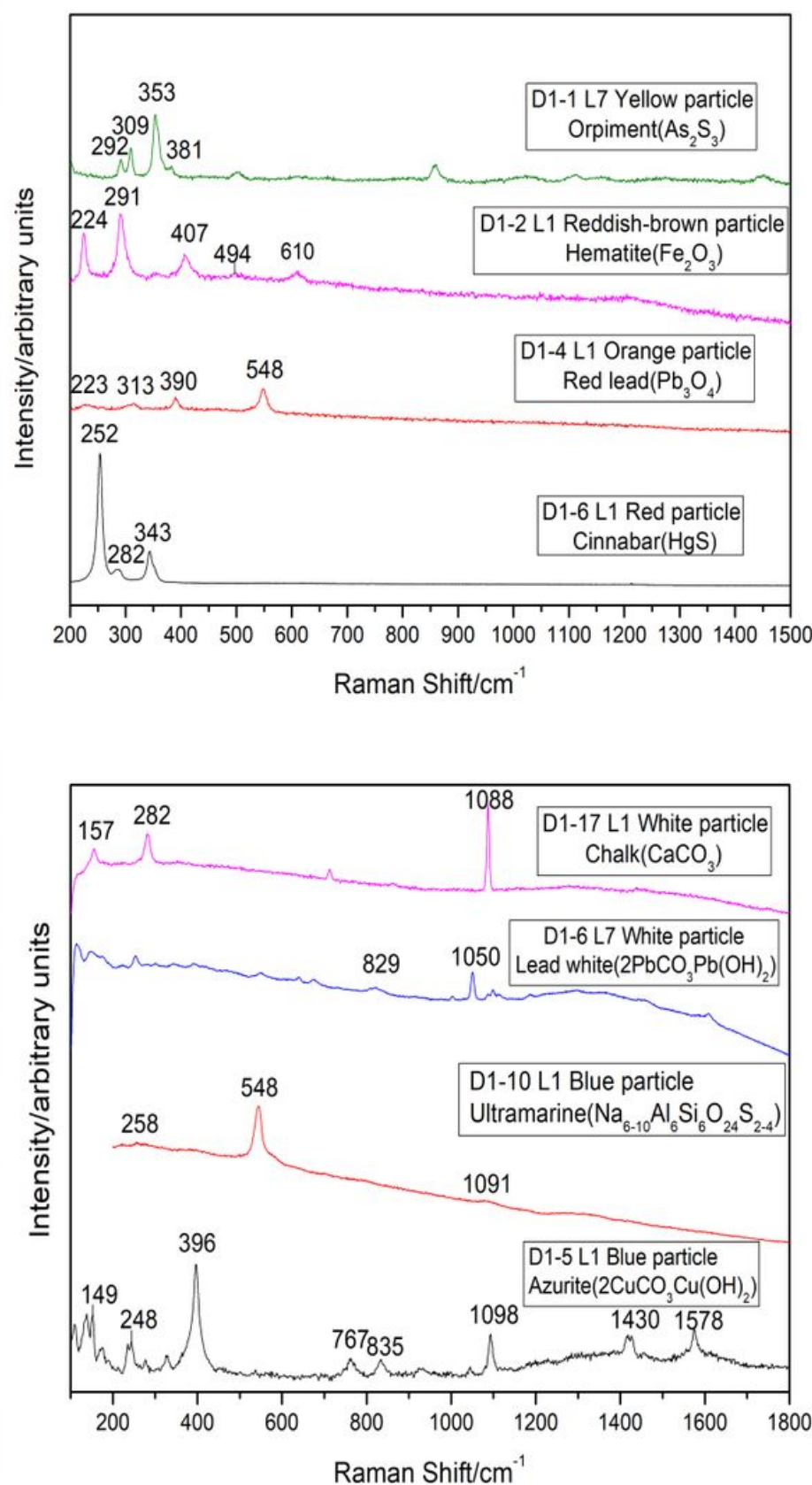

\section{Figure 9}

(a), (c), (e), (g) the cross sections of D1-4, D1-5, D1-6, D1-13, respectively, and (b), (d), (f), (h) are the corresponding backscattered images, (i) the Raman spectrum of orpiment, hematite, red lead and cinnabar, (j) the Raman spectrum of chalk, lead white, ultramarine and azurite. 

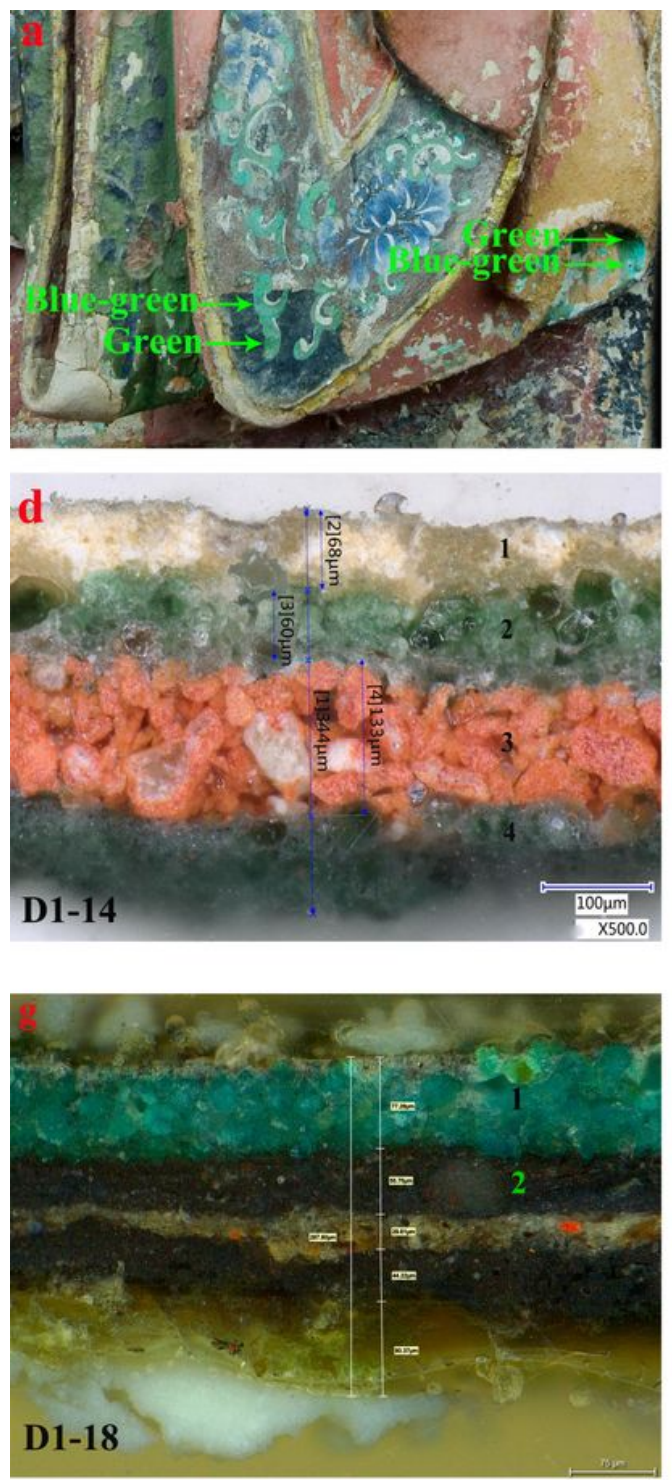
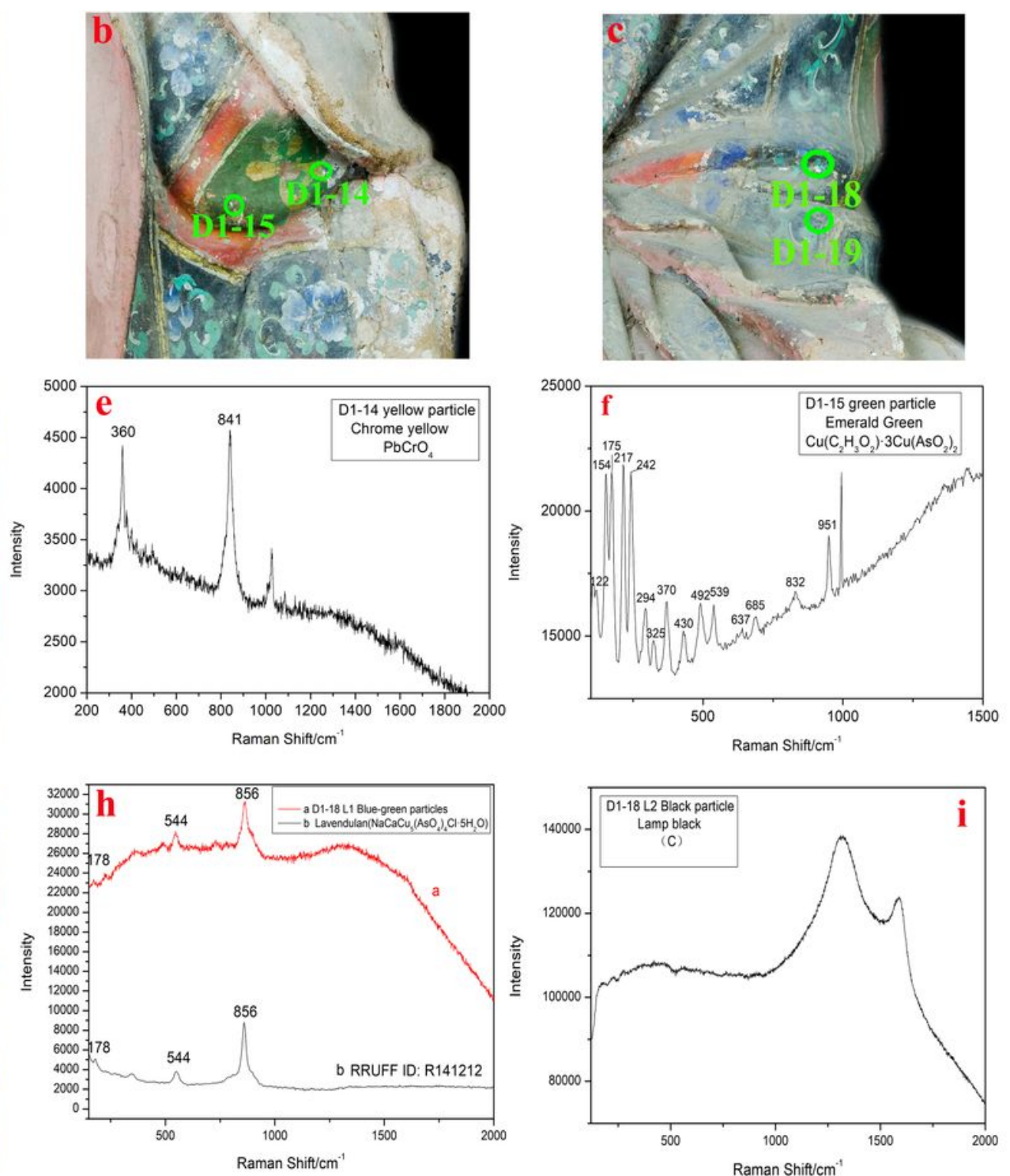
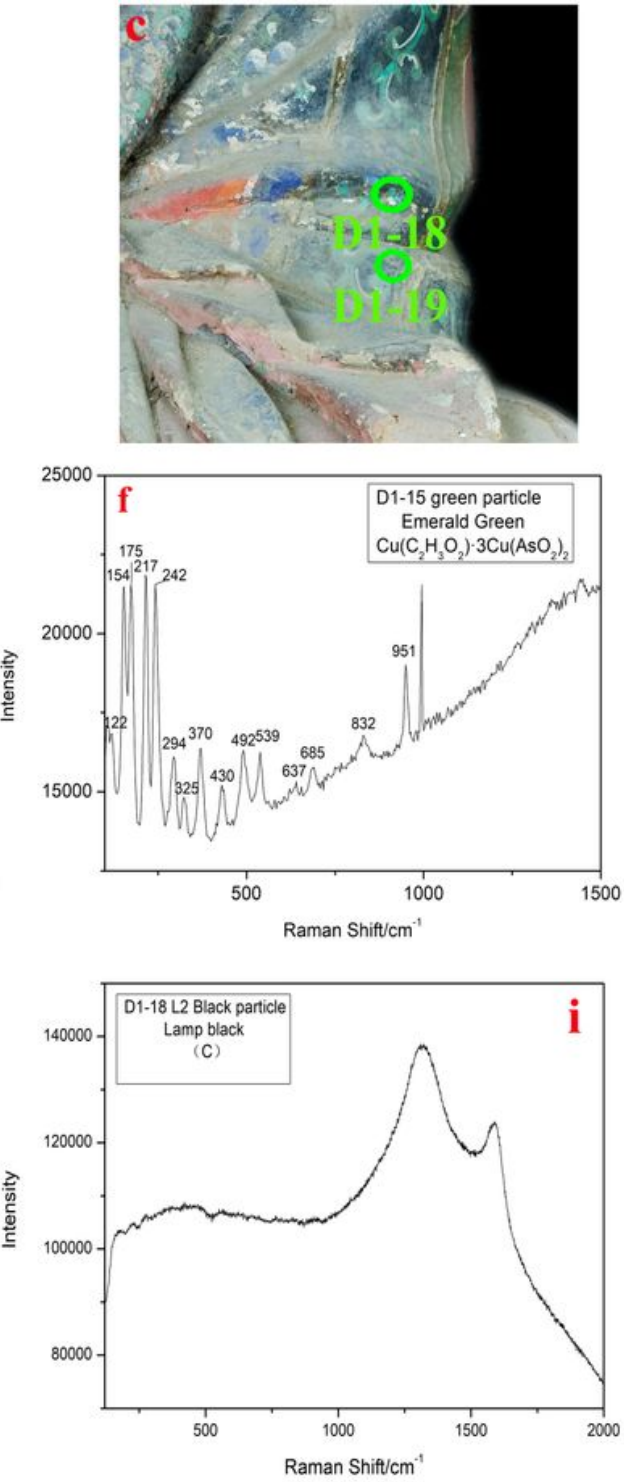

Figure 10

(a) the local area of green and blue-green pigment layers. In the distribution area of blue-green pigment, green pigment and blue-green pigment appear simultaneously or in layers, (b) and (c) the area where samples D1-14, D1-15, D1-18 and D1-19 are located, (d) and (g) the cross section D1-14 and D1-15, (e), (f), (h)and (i) the Raman spectra of chrome yellow, emerald green, lavendulan and lamp black, respectively 

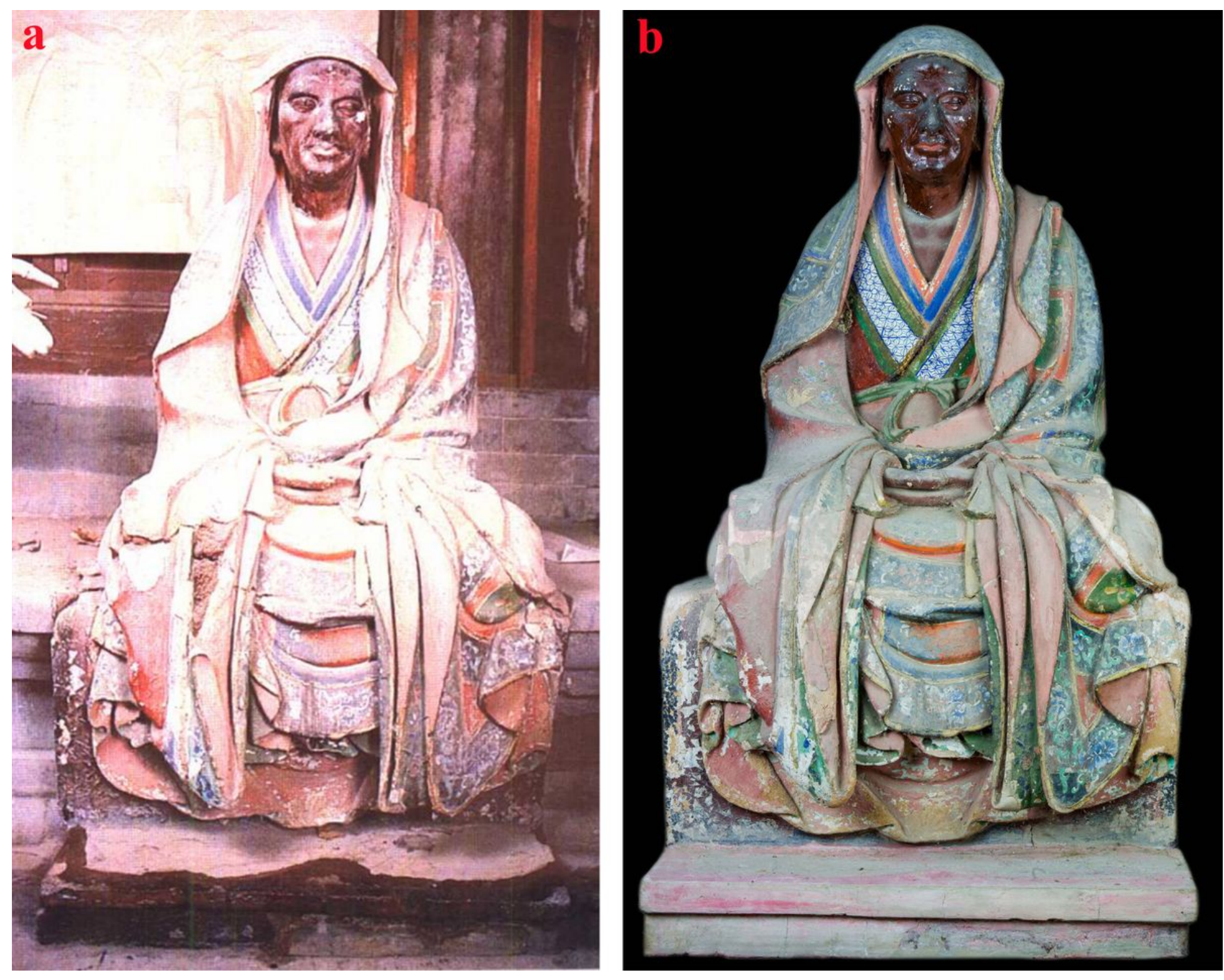

Figure 11

Comparison between the current state of the Bodhidharma Statue and the state before the conservation and restoration in 1981. (a) the state before 1981, and the picture is from literature [29], (b) the current state. 

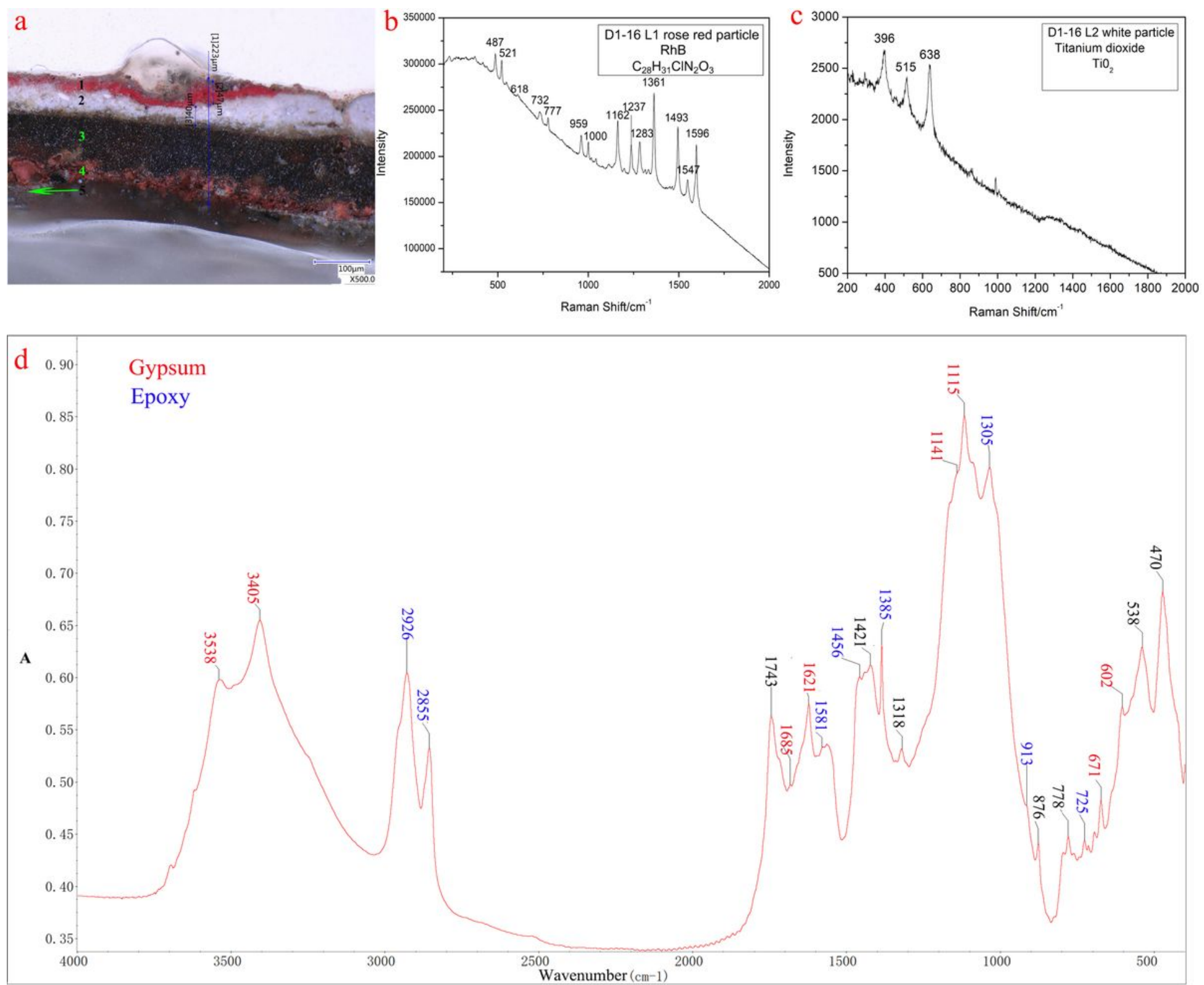

Figure 12

(a) the cross section micrographs of D1-16, (b) the Raman spectrum of L1 rose red organic pigment, (c) the Raman spectrum of L2 titanium dioxide pigment, (d) the infrared spectrum of D1-16

\section{Supplementary Files}

This is a list of supplementary files associated with this preprint. Click to download.

- Additionalfile1.docx 